May 2003 • NREL/TP-550-30301

\title{
Building America System Performance Test Practices: Part 1 - Photovoltaic Systems
}

G. Barker

Mountain Energy Partnership

P. Norton

National Renewable Energy Laboratory

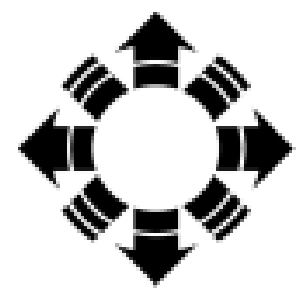

\section{NPEI}

National Renewable Energy Laboratory

1617 Cole Boulevard

Golden, Colorado 80401-3393

NREL is a U.S. Department of Energy Laboratory

Operated by Midwest Research Institute • Battelle • Bechtel

Contract No. DE-AC36-99-G010337 
May 2003 ・ NREL/TP-550-30301

\section{Building America System Performance Test Practices: Part 1 - Photovoltaic Systems}

G. Barker

Mountain Energy Partnership

P. Norton

National Renewable Energy Laboratory

Prepared under Task No. BET3.8004

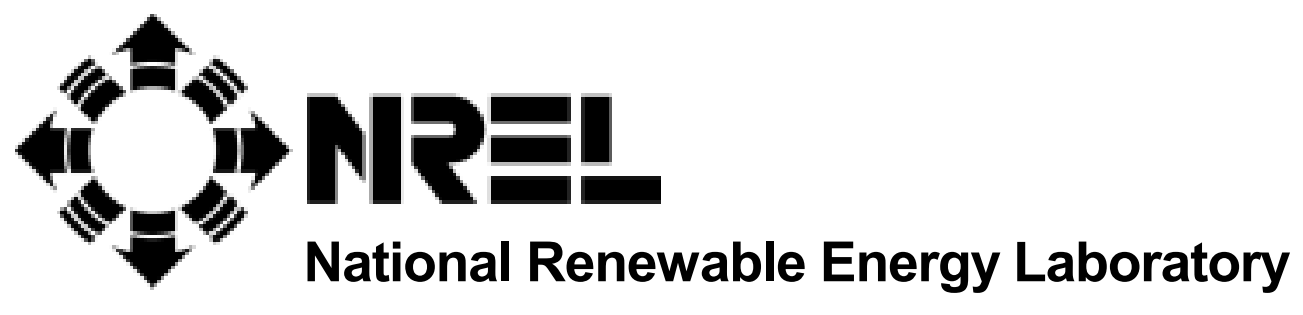

1617 Cole Boulevard

Golden, Colorado 80401-3393

NREL is a U.S. Department of Energy Laboratory

Operated by Midwest Research Institute • Battelle • Bechtel

Contract No. DE-AC36-99-G010337 


\section{NOTICE}

This report was prepared as an account of work sponsored by an agency of the United States government. Neither the United States government nor any agency thereof, nor any of their employees, makes any warranty, express or implied, or assumes any legal liability or responsibility for the accuracy, completeness, or usefulness of any information, apparatus, product, or process disclosed, or represents that its use would not infringe privately owned rights. Reference herein to any specific commercial product, process, or service by trade name, trademark, manufacturer, or otherwise does not necessarily constitute or imply its endorsement, recommendation, or favoring by the United States government or any agency thereof. The views and opinions of authors expressed herein do not necessarily state or reflect those of the United States government or any agency thereof.

Available electronically at http://www.osti.gov/bridge

Available for a processing fee to U.S. Department of Energy and its contractors, in paper, from:

U.S. Department of Energy

Office of Scientific and Technical Information

P.O. Box 62

Oak Ridge, TN 37831-0062

phone: 865.576 .8401

fax: 865.576.5728

email: reports@adonis.osti.gov

Available for sale to the public, in paper, from:

U.S. Department of Commerce

National Technical Information Service

5285 Port Royal Road

Springfield, VA 22161

phone: 800.553.6847

fax: 703.605.6900

email: orders@ntis.fedworld.gov

online ordering: http://www.ntis.gov/ordering.htm 


\section{Table of Contents}

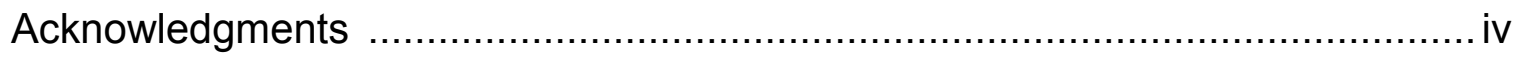

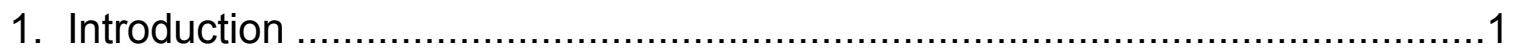

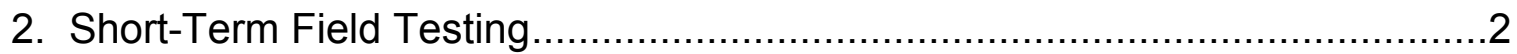

2a. Checking that the Array is Operating Properly ...................................

2b. Maximum Power Point Tracking and Battery Storage ............................... 4

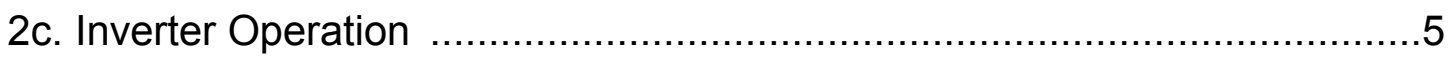

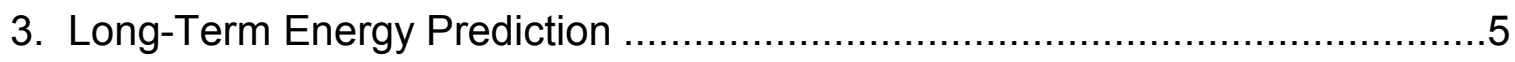

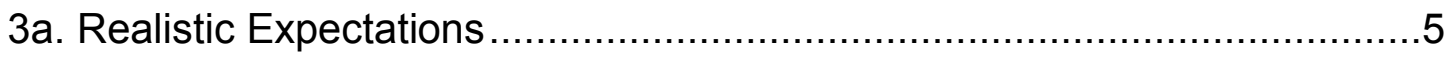

3b. Calibrating an Annual Simulation Model ..............................................

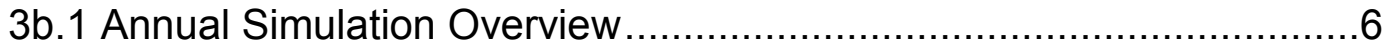

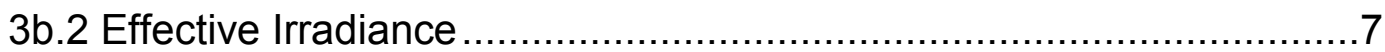

3b.2a Spectral Effects Caused by Air Mass ....................................

3b.2b Incidence Angle Effects .................................................

3b.3 Predicting the Position of Five Points on the I-V Curve ..................10

3b.4 Predicting the Position of Any Point on the I-V Curve.....................10

3b.5 Predicting Module Temperature ...............................................13

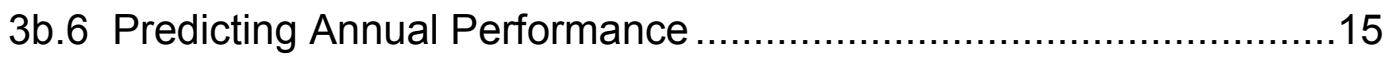

3b.7 Generalizing for Module Types Not in the Sandia Database ...........17

4. Example Application of the Analysis Method: A 630-Watt Nominal

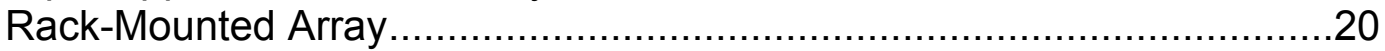

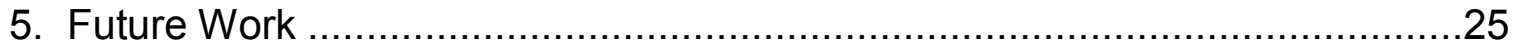

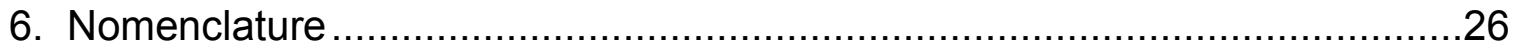

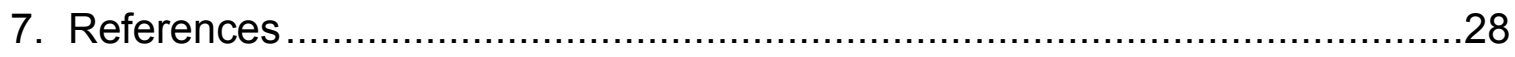

8. Appendix: Code Example in Visual Basic..............................................30 


\section{List of Figures}

Figure 1. Procedure for checking array operation ............................................... 3

Figure 2. Air Mass Modifier as a function of solar zenith angle for all PV modules in the Sandia database. The different types of cell materials are grouped by color. The legend indicates the cell material and the glazing material. Note that the amorphous silicon modules are most sensitive to absolute air mass and, hence, to solar zenith angle. The curves have been limited to the values at solar zenith $=84$ degrees (Air Mass $=10$ ) as the correlations blow up at very high air mass values

Figure 3. Incidence angle modifier as a function of incidence angle for all modules in the Sandia database. The modules fall into three categories with regards to incidence angle modifier: standard cells with a glass cover, cells with an anti-reflective coating covered with glass, and cells covered with a dimpled Tefzel glazing

Figure 4. Example I-V curve showing the five points defined by equations 4 through 9. The TRW equation (Equation 10) tends to overestimate the current on both sides of the maximum power point. Equation 19 fits the measured data quite well....

Figure 5. Four typical mounting schemes for PV arrays, resulting in different module temperatures under the same environmental conditions

Figure 6. Ratio of $\beta_{\mathrm{Vmp}}$ to $\beta_{\mathrm{Voc}}$ (red) and $\alpha_{\text {imp }}$ to $\alpha_{\text {isc }}$ (blue) from the Sandia database of module characteristics

Figure 7. Power-Voltage curves taken every 15 minutes from 11:00 AM to 5:00 PM

Figure 8. Conditions measured during the short-term test of the array. The calculated effective radiation ( $\mathrm{Ic}$,eff) is shown as a dashed line

Figure 9. Key array parameters, measured and predicted from regression ............ 24

Figure 10. Effect of temperature on Vmp and $\mathrm{Voc}$, measured and best-fit 


\section{List of Tables}

Table 1. Convective and Radiative Heat Transfer Parameters

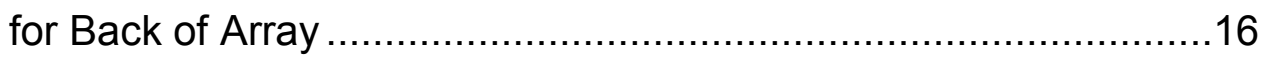

Table 2. $\quad \mathrm{M}_{\mathrm{Ama}}$ Coefficients for Eight Cell Materials ................................18

Table 3. $\quad \mathrm{M}_{\theta \mathrm{i}}$ Coefficients for Three Types of Glazings .............................18

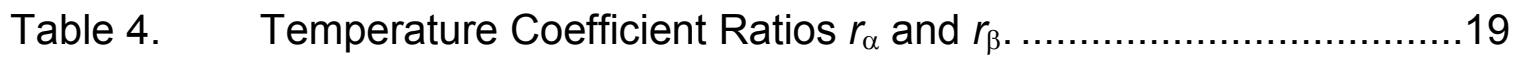

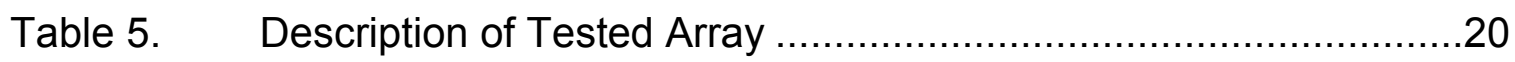

Table 6. Coefficients for Equation 1, taken from Sandia Database for Seimens SM55 PV Module..................................20

Table 7. Coefficients for Equation 2, taken from Sandia Database for Seimens SM55 PV Module....................................20

Table 8. Coefficients for Predicting I-V Curve Under Any $T_{\text {mod }}$ and $I_{c} \ldots \ldots . . .23$

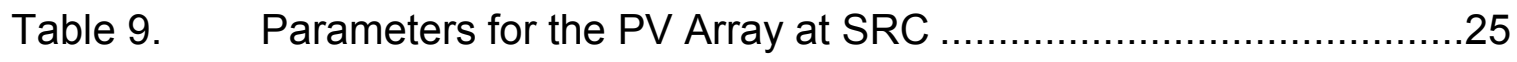

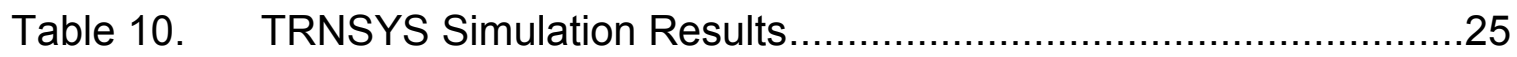




\section{Acknowledgments}

The authors thank Ed Hancock of Mountain Energy Partnership for his valuable technical input; Bob Hendron of the National Renewable Energy Laboratory's Center for Buildings and Thermal Systems for his review of the document; and Keith Emery, Byron Stafford, Ben Kroposki, and Peter McNutt of the National Center for Photovoltaics for their review of the document and perspectives on the approach.

In addition, we thank Mary and Bill Webber for providing access to their home's PV system for testing; Bill Rittelmann of Integrated Building and Construction Solutions (IBACOS), one of the five Building America Program teams, for his support in field testing the PV system used in the example; and Lauren Poole of NREL for her technical editing and document preparation. We also express our gratitude to George James, Department of Energy Program Manager for Building America, for the leadership and resources needed to complete this work. 


\section{Introduction}

The Building America Program is an industry-driven program sponsored by the U.S. Department of Energy (DOE) that uses systems engineering approaches to accelerate the development and adoption of advanced building energy technologies in production housing. Building America partners with crosscutting residential building industry teams to produce advanced residential buildings on a community scale. Residential building systems are evaluated by conducting successive design, test, redesign, build, and retest iterations until cost and performance trade-offs yield innovations that can be implemented in production-scale housing.

The advent of net metering, reduced cost of photovoltaic (PV) systems, and increased electricity costs have led to an increase in home PV systems. PV systems have been included on several Building America houses in Tucson, Arizona; Sylmar, California; Evergreen, Colorado; and Pueblo, Colorado. We expect more PV systems on Building America houses in the coming years. The purpose of this report is to document how Building America answers the following question:

\section{How much electricity is delivered by a home photovoltaic system?}

The report outlines the short-term field testing used by Building America staff and includes a report on the results of an example test of a PV system with battery storage on a home in Tucson, Arizona. This report is not intended as a general recommended test procedure for wide distribution. It is intended to document current practices in Building America to inform program stakeholders and stimulate further discussion. Building America staff intend to apply this procedure until relevant standards for testing PV modules are completed. Standards under development include the proposed Institute of Electrical and Electronics Engineers (IEEE) standards P1479 "Recommended Practice for the Evaluation of Photovoltaic Module Energy Production" and P1526 "Recommended Practice for Testing the Performance of Stand-Alone PV Systems."

The report is organized into three main sections:

(1) Short-term field testing

(2) Long-term performance prediction

(3) Example application of the test and prediction practices.

Over the course of the last few years, we have had the opportunity to inspect and diagnose problems on a number of small PV systems as part of Building America. The systems have included those that are grid-tied with no storage, grid-tied with storage, and stand-alone with storage systems. Surprisingly, all of the systems we have tested have had simple-to-diagnose problems that impeded their energy production. This report describes the procedures we have developed for checking that the system is operating properly and developing a realistic expectation of electricity delivered by the system over a year of operation. 


\section{Short-Term Field Testing}

Short-term field testing of PV systems within the Building America program consists of checking that the system components (array, maximum power-point tracker and/or batteries, and inverter) are operating properly and measuring I-V (current-voltage) curve for the system.

\section{2a. Checking that the Array is Operating Properly}

The flowchart in Figure 1 describes the procedure we use to check the array's operation. The following is a discussion of the numbered boxes in Figure 1.

(1) PV arrays typically consist of groups of modules wired in identical parallel strings. The strings are joined together in a combiner box, which sometimes has a fuse for each string. We have found more than once that at least one string is producing little or no power for a variety of reasons.

We have found that the easiest way of identifying this type of problem is to measure the current coming from each string using a clamp-on DC ammeter under normal PV system operation. On a balanced array, as long as the incident solar radiation on the array is not changing rapidly (as happens when there are clouds near the sun) and as long as there is no shading on the array, each string should be producing a similar current.

Installers often measure the open-circuit voltage of each string as a way of checking that each string is operating properly. This can be misleading, because a blown fuse or disconnected wire can allow a "floating" voltage reading that appears to be correct. A test of the short-circuit current of each string would provide good information on the operation of each string, but this can be a safety hazard because of electrical arcing.

(2) Because all the strings are connected in parallel, the voltage across each string is the same. Assuming that each string is identical in model and number of modules, there is no shading, and the modules are all in the same plane, the current produced by each string should be close. They are unlikely to be exactly the same, as differences in wire connections, dirt on the collectors, and individual module efficiency will cause some mismatch.

(3) If there is obviously a problem with the array, but no obvious easy fix such as replacing a blown fuse or reconnecting a wire, then we generally do not continue testing the system until the service personnel has been notified and the array has been fixed.

(4) Typically we measure the current being delivered by the array with a clamp-on DC Halleffect ammeter. Often the current is also displayed as part of the inverter, but the resolution is often too coarse, especially if the inverter is oversized compared to the array. The incident global solar irradiance is measured using a thermopile-type pyronometer. The back-of-module temperature is used as a close surrogate for the cell temperature and is measured by adhering a temperature sensor to the back of one module with adhesive tape. 
(1) Measure current from each string under normal operation and steady, unshaded conditions

(2) Are all currents within $10 \%$ of each other?

\section{$\mathrm{NO}$}

Check fuses (if any) for each string.

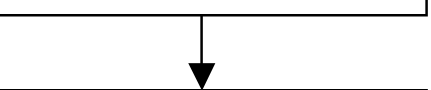

Look for obvious wire disconnects.

Discontinue testing, call service personnel to repair string(s). Begin testing after repairs are completed.

\section{YES}

$\mathrm{NO}$

(4) Measure under normal operation and steady, unshaded conditions:

- Array Current

- Array Voltage

- Incident global solar irradiance

- Back-of-module temperature

(5) Compare measured power output of array to theoretical expected value at test conditions

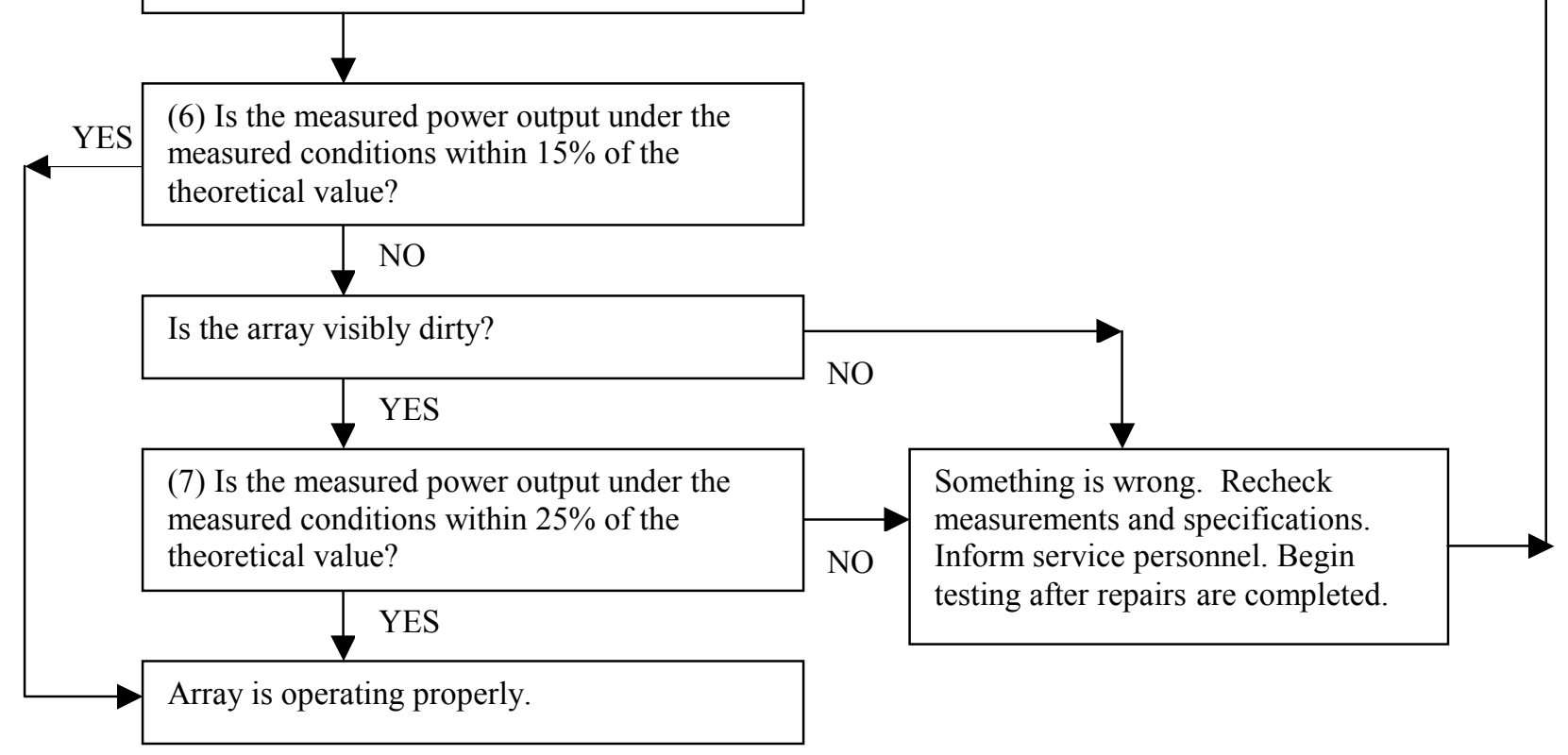

Figure 1. Procedure for checking array operation 
(5) There is no guarantee that the array is operating at the maximum power point, so simply scaling the manufacturer's maximum power at standard test conditions to the cell temperature and the irradiance will not necessarily give the theoretical power output under the measured conditions. The shape of the Power-Voltage curve under the test conditions must be calculated.

The theoretical power output of the array is determined by drawing the theoretical PowerVoltage $(\mathrm{P}-\mathrm{V})$ curve under the measured irradiance and cell temperature. This $\mathrm{P}-\mathrm{V}$ curve is then used to determine the theoretical power output at the measured array voltage. Many models of PVs have been measured and characterized by Sandia National Laboratories (Sandia); for these models, we draw the I-V curve using software called "IV Tracer" [1], which implements the characterization model developed by King et al. [2] If the PV module model is not in the Sandia database, then a theoretical I-V curve for the test conditions can be drawn using the techniques described in Duffie and Beckman [3].

(6) An array should be expected to operate up to $15 \%$ less efficiently than what one would expect from theoretical values. This is because the theoretical value does not take into account mismatch between modules, increased series resistance caused by wiring and connections, and biases between factory-reported efficiencies and actual efficiencies of the modules. In addition, the error in the solar irradiance measurement is typically $\pm 5 \%$. In this portion of our testing, we are simply trying to determine whether or not there is a serious problem with the array, not precisely characterize the array.

(7) We have observed that in a dry, dusty climate, the accumulated dirt on an array can cause up to a $10 \%$ degradation in power output. Of course, the degradation can be more or less depending on how dirty the array is, but $10 \%$ seems to be a reasonable number for a visibly dirty array. Thus the acceptable discrepancy in power output is increased from $15 \%$, given in item (6), to $25 \%$.

\section{2b. Maximum Power Point Tracking and Battery Storage}

More often than not, a small PV system (less than 4 rated $\mathrm{kW}$ ) does not include a maximum power point tracker (MPPT). Systems with storage (batteries) generally operate the array at the battery voltage that, for a well-matched array, is close to the maximum power voltage under many conditions. Systems without storage generally have some type of MPPT.

Using the methods described in item (5) in Section 2a, we compare the maximum power under the measured irradiance and cell temperature to the power at the measured operating voltage. This difference is the percent reduction in performance caused by imperfect maximum power point tracking. The absolute power output of the actual array may differ from the theoretical as described in notes (5) and (6) of Section 2a, but the percent reduction resulting from imperfect maximum power point tracking is expected to be similar for the absolute and theoretical power output. This procedure does not give a prediction of loss of power over an extended period, but it does give a clue as to how close the tracking is. A few related experiences are worth noting:

- One grid-tied, no-storage system we tested repeatedly tracked the array at a voltage higher than the maximum power voltage, resulting in a 50\% sacrifice in delivered energy. 
- Another grid-tied, no-storage system was observed to track the voltage erratically, jumping in voltage by large increments every few minutes, resulting in at least a $10 \%$ sacrifice in delivered energy.

- A grid-tied system with storage had a battery bank with a nominal voltage of $48 \mathrm{~V}$, while the array attached to it (without a MPPT) had a nominal voltage at maximum power of $71 \mathrm{~V}$. This resulted in an operating voltage consistently below the maximum power point voltage and caused up to a $20 \%$ sacrifice in power production, depending on environmental conditions. (This example is described in detail later in this report.)

\section{2c. Inverter Operation}

An inverter we commonly encounter in $0.5-$ to $4.0-\mathrm{kW}$ systems is the Trace SW4048 inverter. This is a very versatile inverter, with a wide variety of programming options accessed through a series of menus on the front panel. We have found on more than one occasion that a simple programming error caused the PV system to malfunction. Because of this experience, we routinely go through the menu settings on the inverter to check that they are correct. The efficiency of the inverter is generally not in question and is well characterized by the factory. (We confirmed the factory efficiency curve using long-term measurements on one system.) A quick check of the measured output power using a watt transducer on the AC side divided by the measured input DC power is generally made to confirm that the inverter is operating as expected.

\section{Long-Term Energy Prediction}

\section{3a. Realistic Expectations}

Because the standard reference conditions (SRC) used to defined rated power of PV modules $\left(1000 \mathrm{~W} / \mathrm{m}^{2}, 25^{\circ} \mathrm{C}\right.$ cell temperature) does not represent average in-use conditions, consumers often expect both the instantaneous and annual energy production of a PV system to be higher than it actually is. For example, a system rated at $2.5 \mathrm{~kW}$ will only generate $2.5 \mathrm{~kW}$ under full sun, when the air temperature is below freezing, the inverter is $100 \%$ efficient, and the array is operated at its maximum power point voltage. From annual simulations, we have found that for the United States, the daily energy production of a typical system with an inverter can be estimated by assuming 4 to 5 full rated hours per day. For example, a system rated at $2.5 \mathrm{~kW}$ can be expected to produce between $10 \mathrm{kWh}(4 \mathrm{hr} \times 2.5 \mathrm{~kW})$ and $12.5 \mathrm{kWh}(5 \mathrm{hr} \times 2.5 \mathrm{~kW})$ of energy per day on average. The annual energy production of a system can also be estimated using NREL's web-based PV sizing software, PWWATTS, for grid-connected systems with a MPPT (http://rredc.nrel.gov/solar/codes_algs/PVWATTS/) or commercial simulation software such as PV-DESIGNPRO, available from Maui Solar Energy Software Corporation (http://www.mauisolarsoftware.com/).

\section{3b. Calibrating an Annual Simulation Model}

To accurately predict annual energy production of a particular PV system, it is necessary to calibrate the theoretical model using short-term tests to accurately represent the behavior of the actual system under all expected conditions. This involves fitting data from a family of I-V curves taken using an I-V curve tracer from a short-term (1 to 3 days) test of a PV array to a set 
of polynomial functions. These functions are used to predict the array's behavior under a wide range of temperatures and irradiances. TRNSYS [4], driven by TMY2 [5] weather data, is used to simulate the array's behavior under typical weather conditions.

\section{3b.1. Annual Simulation Overview}

The manufacturer of a PV module will typically supply data that describes a module's voltage and current characteristics under standard test conditions $\left(\mathrm{I}_{\mathrm{c}}=1000 \mathrm{~W} / \mathrm{m}^{2}, \mathrm{~T}_{\mathrm{c}}=25^{\circ} \mathrm{C}\right)$. Often, temperature coefficients for voltage and current are also supplied, which can nominally be used to translate the points on an I-V curve from standard test conditions to other cell temperature conditions. Current output from the module is usually assumed linear with incident irradiance. To predict the performance of an array of modules, the manufacturer's test data for a single module are typically assumed to be accurate for each module in the array, scaling by the number of modules in series and parallel. To account for differences between manufacturers' specifications and actual modules' performance a "derate factor" is sometimes added in, but there is no quantitative way of establishing this derate factor; it is inserted using engineering judgment and experience that "PV arrays don't perform as well as the manufacturer's specifications." In fact, the difference between expected and actual performance is rarely as simple as a constant derate factor.

When testing PV arrays in the field, we usually find that the power output of the array is lower than was predicted using the above method. This can be for a number of reasons:

(1) The average module installed in the array is not as efficient as the module tested by the manufacturer because of manufacturing inconsistencies.

(2) The system does not employ a maximum power point tracking device, and the voltage of the controller setpoint is not always at the maximum power point voltage. In some systems we have found that the controller setpoint is never particularly near the maximum power voltage.

(3) Connections between modules and wires to and from the array create voltage drop and power loss in the array.

(4) Solar incidence angle effects result in less collected energy at sharp beam incidence angles.

(5) Performance dependence on the spectral content of irradiance has not been taken into account.

Rather than rely on the manufacturer's module-level data for predicting a PV array's performance, it is desirable to test the array in-situ over a short period ( 1 to 3 days) to characterize its behavior. This characterization can then be used in an annual simulation driven by TMY2 data to predict its behavior under typical weather conditions. Using a method for extrapolating short-term measured data to long-term performance is a reasonable way to compare the performance of one system to another: how they compare under typical and identical driving weather conditions .

King [6] and King et al. [7] have done quite a bit of work toward this endeavor. We have simplified their approach and added some general correlations to predict certain performance parameters for PV's for which there may be limited information from the manufacturer. In general, the method involves measuring I-V curves for the entire array over the period of one 
clear day (sunrise to sunset) to obtain curves under a range of irradiances and cell temperatures. Five points along the I-V curve (short-circuit, maximum power, open circuit, and two intermediate points) are defined in terms of polynomials as a function of irradiance and back-ofmodule temperature. For any irradiance and module temperature the position of five points on the I-V curve can be calculated and a curve drawn connecting them. An annual simulation such as TRNSYS can then be used to predict power output of the array for every hour of a typical year given knowledge of the voltage tracking characteristics of the controller.

In the following sections of this paper, we describe in detail the various steps that are taken in starting with data from a short-term test and arriving with a prediction of annual energy production of a PV array.

\section{3b.2. Effective Irradiance}

The effective irradiance $\left(\mathrm{I}_{\mathrm{c}, \mathrm{eff}}\right)$ is defined as the equivalent global irradiance that would be falling on the surface of the array if the sun was directly overhead and the array was horizontal. In the approach presented in this paper, the performance of the $\mathrm{PV}$ array is expressed in terms of $\mathrm{I}_{\mathrm{c}, \text { eff. }}$. The effective irradiance is affected by two phenomena: spectral effects and incidence angle effects.

\section{3b.2a. Spectral Effects Caused by Air Mass}

Absolute air mass $\left(\mathrm{A}_{\mathrm{ma}}\right)$ is defined as the ratio of mass of atmosphere through which beam radiation passes to the mass it would pass through if the sun were directly overhead. As the air mass increases, the spectral content of irradiance changes. For some PVs, notably amorphous, this has an effect on the efficiency of the PV. King [6] and King et al. [7] characterized this dependency in the form of a polynomial as a function of $\mathrm{A}_{\mathrm{ma}}$ for several different types of PV modules. A database containing the values of the polynomial constants are available from the Sandia National Laboratory web site. The form of the equation for the Air Mass Modifier $\left(\mathrm{M}_{\mathrm{Ama}}\right)$ is as follows:

$$
M_{\text {Ama }}=a_{0}+a_{1} * A_{m a}+a_{2} * A_{m a}{ }^{2}+a_{3} * A_{m a}{ }^{3}+a_{4} * A_{m a}{ }^{4}
$$

The shapes of $\mathrm{M}_{\mathrm{Ama}}$ as a function of solar zenith angle for all PV modules in the Sandia database are shown in Figure 2. The reader may notice that the curves do not all fall on $\mathrm{M}_{\mathrm{Ama}}=1.0$ at a solar zenith angle of zero as they theoretically should; this is most likely because of to a less-than-perfect correlation. 


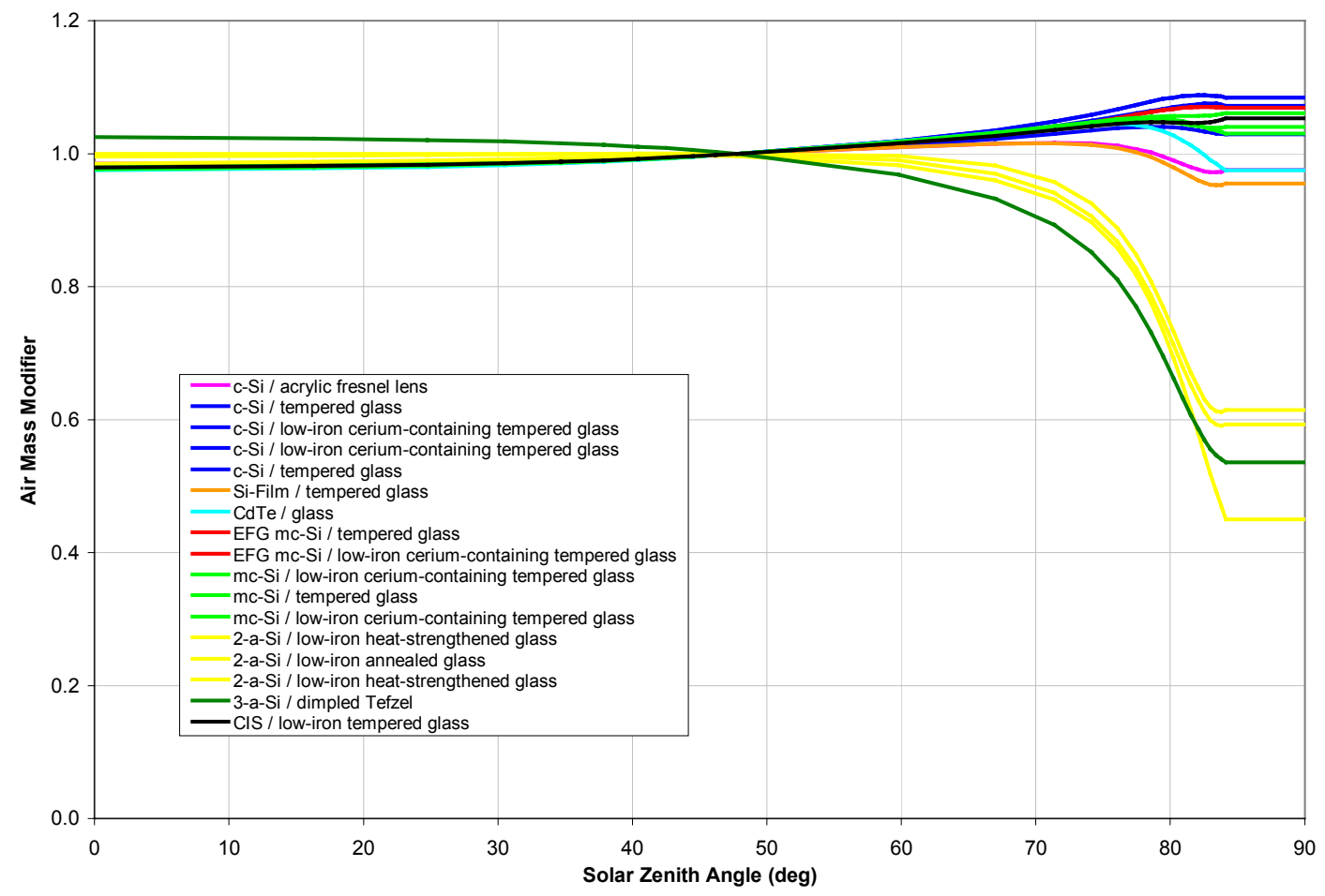

Figure 2. Air Mass Modifier as a function of solar zenith angle for all PV modules in the Sandia database. The different types of cell materials are grouped by color. The legend indicates the cell material and the glazing material. Note that the amorphous silicon modules are most sensitive to absolute air mass, and hence to solar zenith angle. The curves have been limited to the values at solar zenith $=84$ degress (Air Mass=10) as the correlations blow up at very high air mass values.

\section{3b.2b. Incidence Angle Effects}

The incidence angle $\left(\theta_{\mathrm{i}}\right)$ is the angle between the direction of beam irradiance and a normal to the surface of the PV. With the sun directly overhead and the array horizontal, the incidence angle is zero. As the incidence angle increases a greater portion of beam radiation is reflected from the glazing surface. King [6] and King et al. [7] characterized this behavior in the form of a polynomial for several different PV types:

$\mathrm{M}_{\theta \mathrm{i}}=\mathrm{b}_{0}+\mathrm{b}_{1} \theta_{\mathrm{i}}+\mathrm{b}_{2} \theta_{\mathrm{i}}^{2}+\mathrm{b}_{3} \theta_{\mathrm{i}}{ }^{3}+\mathrm{b}_{4} \theta_{\mathrm{i}}^{4}+\mathrm{b}_{5} \theta_{\mathrm{i}}{ }^{5}$

The values of $\mathrm{M}_{\theta \mathrm{i}}$ for all modules in the Sandia database are shown as a function of incidence angle in Figure 3. 


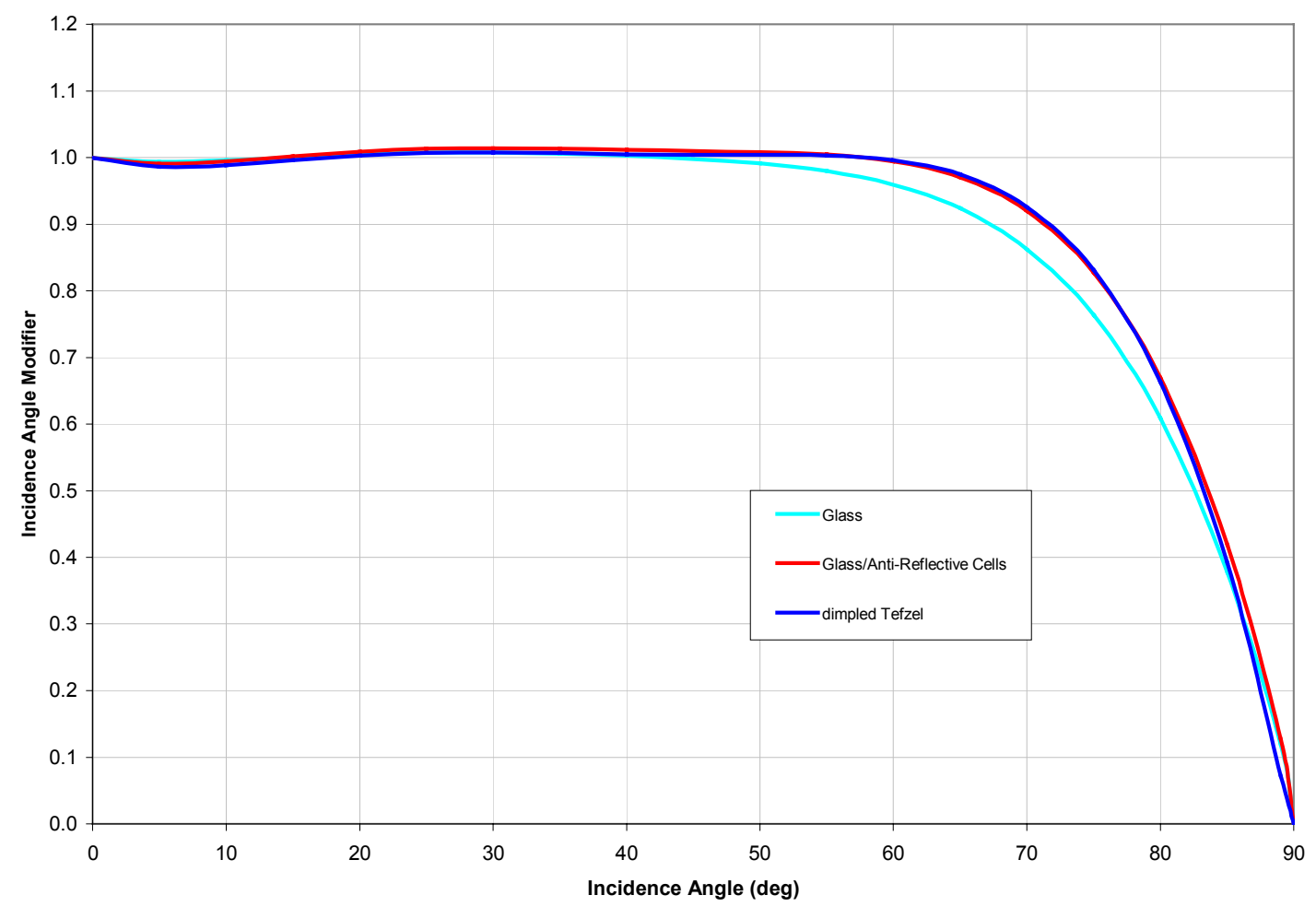

Figure 3. Incidence angle modifier as a function of incidence angle for all modules in the Sandia database. The modules fall into three categories with regards to incidence angle modifier: standard cells with a glass cover, cells with an antireflective coating covered with glass, and cells covered with a dimpled Tefzel glazing.

The effective irradiance, which is the irradiance incident on the plane of the array modified by $\mathrm{M}_{\mathrm{Ama}}$ and $\mathrm{M}_{\theta \mathrm{i}}$, can then be expressed as:

$$
I_{c, e f f}=M_{A m a} *\left(M_{\theta i} * I_{b}+I_{d}\right)
$$

Note that the air mass modifier affects both the beam and diffuse components of irradiance, whereas the incidence angle modifier affects only the beam portion. Typically only the global irradiance in the plane of the array is measured during testing; the split between beam and diffuse can be approximated using a correlation developed by Erbs [8] for estimating the beam and diffuse components of global horizontal irradiance, a correlation developed by Hay and Davies [9] for estimating the beam and diffuse components on a sloped surface, and an estimate of ground reflectance. A code example in Visual Basic implementing this technique can be found in the appendix. 


\section{3b.3. Predicting the Position of Five Points on the I-V Curve}

King [6] and King et al. [7] proposed that under any one set of irradiance and temperature conditions, five points on the I-V curve can be used to define the shape of the curve:

(1) $\mathrm{i}=\mathrm{i}_{\mathrm{sc}}, \quad \mathrm{V}=0$

(2) $\mathrm{i}=\mathrm{i}_{\mathrm{x}}, \quad \mathrm{V}=0.5 * \mathrm{~V}_{\mathrm{oc}}$

(3) $\mathrm{i}=\mathrm{i}_{\mathrm{mp}}, \mathrm{V}=\mathrm{V}_{\mathrm{mp}}$

(4) $\mathrm{i}=\mathrm{i}_{\mathrm{xx}}, \quad \mathrm{V}=0.5 *\left(\mathrm{~V}_{\mathrm{mp}}+\mathrm{V}_{\mathrm{oc}}\right)$

(5) $\mathrm{i}=0, \quad \mathrm{~V}=\mathrm{V}_{\mathrm{oc}}$

These five points are each characterized as a function of $\left(\mathrm{I}_{c, \text { eff }}-\mathrm{I}_{\mathrm{c} 0}\right)$ and $\left(\mathrm{T}_{\bmod }-\mathrm{T}_{\bmod 0}\right)$ according to equations 4 through 9. Here we have adopted King's general approach, but simplified the equations somewhat to make them easier to grasp:

$$
\begin{aligned}
& \mathrm{i}_{\mathrm{sc}}=\mathrm{i}_{\mathrm{sc} 0}\left[1+\left(\mathrm{I}_{\mathrm{c}, \mathrm{eff}}-\mathrm{I}_{\mathrm{c} 0}\right) / \mathrm{I}_{\mathrm{c} 0}\right]\left[1+\alpha_{\mathrm{isc}}\left(\mathrm{T}_{\bmod }-\mathrm{T}_{\bmod 0}\right)\right] \\
& \mathrm{i}_{\mathrm{x}}=\mathrm{i}_{\mathrm{x} 0}\left\{1+\mathrm{c}_{1}\left[\left(\mathrm{I}_{\mathrm{c}, \text { eff- }}-\mathrm{I}_{\mathrm{c} 0}\right) / \mathrm{I}_{\mathrm{c} 0}\right]+\mathrm{c}_{2}\left[\left(\mathrm{I}_{\mathrm{c}, \text { eff }}-\mathrm{I}_{\mathrm{c} 0}\right) / \mathrm{I}_{\mathrm{c} 0}\right]^{2}\right\}\left[1+\alpha_{\mathrm{ix}}\left(\mathrm{T}_{\text {mod }}-\mathrm{T}_{\bmod 0}\right)\right] \\
& \mathrm{i}_{\mathrm{mp}}=\mathrm{i}_{\mathrm{mp} 0}\left\{1+\mathrm{d}_{1}\left[\left(\mathrm{I}_{\mathrm{c}, \text { eff }}-\mathrm{I}_{\mathrm{c} 0}\right) / \mathrm{I}_{\mathrm{c} 0}\right]+\mathrm{d}_{2}\left[\left(\mathrm{I}_{\mathrm{c}, \text { eff- }} \mathrm{I}_{\mathrm{c} 0}\right) / \mathrm{I}_{\mathrm{c} 0}\right]^{2}\right\}\left[1+\alpha_{\mathrm{imp}}\left(\mathrm{T}_{\text {mod }}-\mathrm{T}_{\bmod 0}\right)\right] \\
& \mathrm{i}_{\mathrm{xx}}=\mathrm{i}_{\mathrm{xx} 0}\left\{1+\mathrm{e}_{1}\left[\left(\mathrm{I}_{\mathrm{c}, \text { eff }} \mathrm{I}_{\mathrm{c} 0}\right) / \mathrm{I}_{\mathrm{c} 0}\right]+\mathrm{e}_{2}\left[\left(\mathrm{I}_{\mathrm{c}, \text { eff }}-\mathrm{I}_{\mathrm{c} 0}\right) / \mathrm{I}_{\mathrm{c} 0}\right]^{2}\right\}\left[1+\alpha_{\mathrm{ixx}}\left(\mathrm{T}_{\bmod }-\mathrm{T}_{\bmod 0}\right)\right] \\
& \mathrm{V}_{\mathrm{mp}}=\mathrm{V}_{\mathrm{mp} 0}+\mathrm{f}_{1}\left(\mathrm{I}_{\mathrm{c}, \text { eff }}-\mathrm{I}_{\mathrm{c} 0}\right)+\mathrm{f}_{2}\left(\mathrm{I}_{\mathrm{c}, \text { eff }}-\mathrm{I}_{\mathrm{c} 0}\right)^{2}+\beta_{\mathrm{Vmp}}\left(\mathrm{T}_{\text {mod }}-\mathrm{T}_{\text {mod } 0}\right) \\
& \mathrm{V}_{\mathrm{oc}}=\mathrm{V}_{\mathrm{oc} 0}+\mathrm{g}_{1}\left(\mathrm{I}_{\mathrm{c}, \text { eff }}-\mathrm{I}_{\mathrm{c} 0}\right)+\mathrm{g}_{2}\left(\mathrm{I}_{\mathrm{c}, \mathrm{eff}}-\mathrm{I}_{\mathrm{c} 0}\right)^{2}+\beta_{\mathrm{Voc}}\left(\mathrm{T}_{\text {mod }}-\mathrm{T}_{\text {mod } 0}\right)
\end{aligned}
$$

\section{3b.4. Predicting the Position of Any Point on the I-V Curve}

Using equations 4 through 9 , five points on the I-V curve are defined for any pair of module temperature and irradiance. The task is then to fit a curve through these five points so that for any voltage between zero and $\mathrm{V}_{\mathrm{oc}}$ the current output of the array can be predicted. Luft et al., in work done for TRW Inc. [10], proposed an equation form that fits I-V curves quite well:

$$
\mathrm{i}_{\mathrm{TRW}}=\mathrm{i}_{\mathrm{sc}} *\left[1-\mathrm{k}_{2} *\left(\mathrm{e}^{\left(\mathrm{V} /\left(\mathrm{k}_{1} * \mathrm{~V}_{\mathrm{oc}}\right)\right)}-1\right)\right]
$$

where:

$$
\begin{aligned}
& \mathrm{k}_{1}=\left(\mathrm{V}_{\mathrm{mp}} / \mathrm{V}_{\mathrm{oc}}-1\right) / \operatorname{Ln}\left(1-\mathrm{i}_{\mathrm{mp}} / \mathrm{i}_{\mathrm{sc}}\right) \\
& \mathrm{k}_{2}=\left(1-\mathrm{i}_{\mathrm{mp}} / \mathrm{i}_{\mathrm{sc}}\right) * \mathrm{e}^{\left[-\mathrm{V}_{\mathrm{mp}} /\left(\mathrm{k}_{1} * \mathrm{~V}_{\mathrm{oc}}\right)\right]}
\end{aligned}
$$

Equation 10 is attractive because it involves only the known values of current and voltage at the short-circuit, maximum power, and open-circuit points. The Hart and Raghuraman [11] noted, however, that Equation 10 tends to slightly overestimate current as a function of voltage between $V=0$ and $V=V_{m p}$. To force a more exact fit through the two remaining points $\left(i_{x}, V_{x}\right.$ and $\left.i_{x x}, V_{x x}\right)$ predicted by equations 5 and 7, we have employed the classical single diode model of a photovoltaic module:

$$
\mathrm{i}=\mathrm{i}_{\mathrm{L}}-\mathrm{i}_{\mathrm{o}} *\left(\mathrm{e}^{[(\mathrm{V}+\mathrm{i} * \mathrm{Rs}) / \mathrm{z}]}-1\right)-\left(\mathrm{V}+\mathrm{i} * \mathrm{R}_{\mathrm{s}}\right) / \mathrm{R}_{\mathrm{sh}}
$$


In the past, researchers attempted to define the behavior of an array under all temperature and irradiance conditions using Equation 13 and the five constants $i_{L}, i_{0}, R_{s}, R_{s h}$, and $z$. We have found that this is not a very robust approach and does not fit the array's behavior well under all conditions. Our approach is to use Equation 13 as an equation form that fits the five points described by equations 4 through 9 well under a particular pair of temperature and irradiance conditions. The constants $i_{L}, i_{0}, R_{s}, R_{s h}$, and $z$ may be completely different for a different temperature or irradiance.

To find the best fit for the five constants in Equation 13, we first reduce the equation to one with two unknown constants, $R_{s}$ and $z$. This is done by recognizing that $i=0$ at $V=V_{o c}$ and solving for $i_{L}$ :

$$
\mathrm{i}_{\mathrm{L}}=\mathrm{V}_{\mathrm{oc}} / \mathrm{R}_{\mathrm{sh}}+\mathrm{i}_{\mathrm{o}} *\left(\mathrm{e}^{\mathrm{V}_{\mathrm{oc}} / \mathrm{z}}-1\right) .
$$

We can then substitute Equation 14 into Equation 13 and solve for $i_{o}$, recognizing that $V=0$ at $i=i_{s c}$ :

$$
\mathrm{i}_{\mathrm{o}}=\left(\mathrm{i}_{\mathrm{sc}} * \mathrm{R}_{\mathrm{sh}}+\mathrm{i}_{\mathrm{sc}} * \mathrm{R}_{\mathrm{s}}-\mathrm{V}_{\mathrm{oc}}\right) / \mathrm{R}_{\mathrm{sh}} /\left(\mathrm{e}^{\left(\mathrm{V}_{\mathrm{oc}} / \mathrm{z}\right)}-\mathrm{e}^{\left(\mathrm{I}_{\mathrm{sc}} * \mathrm{R}_{\mathrm{s}} / \mathrm{z}\right)}\right)
$$

Equations 14 and 15 can then be substituted into Equation 13 to solve for $R_{s h}$, recognizing that $i=i_{m p}$ at $V=V_{m p}$ :

$$
\begin{aligned}
& \mathrm{R}_{\mathrm{sh}}=\left[\left(\mathrm{i}_{\mathrm{sc}} * \mathrm{R}_{\mathrm{s}}-\mathrm{V}_{\mathrm{oc}}\right) *\left(\mathrm{e}^{\left(\mathrm{V}_{\mathrm{oc}} / \mathrm{z}\right)}-\mathrm{e}^{\left[\left(\mathrm{V}_{\mathrm{mp}}+\mathrm{I}_{\mathrm{mp}} * \mathrm{R}_{\mathrm{s}}\right) / \mathrm{z}\right]}\right)+\left(\mathrm{V}_{\mathrm{oc}}-\mathrm{V}_{\mathrm{mp}}-\mathrm{i}_{\mathrm{mp}} * \mathrm{R}_{\mathrm{s}}\right) *\right. \\
& \left.\left(\mathrm{e}^{\left(\mathrm{V}_{\mathrm{oc}} / \mathrm{z}\right)}-\mathrm{e}^{\left(\mathrm{i}_{\mathrm{sc}} * \mathrm{R}_{\mathrm{s}} / \mathrm{z}\right)}\right)\right] /\left[\mathrm{i}_{\mathrm{mp}} *\left(\mathrm{e}^{\left(\mathrm{V}_{\mathrm{oc}} / \mathrm{z}\right)}-\mathrm{e}^{\left(\mathrm{i}_{\mathrm{sc}} * \mathrm{R}_{\mathrm{s}} / \mathrm{z}\right)}\right)+\mathrm{i}_{\mathrm{sc}} *\left(\mathrm{e}^{\left[\left(\mathrm{V}_{\mathrm{mp}}+\mathrm{I}_{\mathrm{mp}} * \mathrm{R}_{\mathrm{s}}\right) / \mathrm{z}\right]}-\mathrm{e}^{\left(\mathrm{V}_{\mathrm{oc}} / \mathrm{z}\right)}\right)\right] .
\end{aligned}
$$

It is possible to then substitute Equation 16 into equations 14 and 15 to get rid of the $R_{s h}$ terms, then substitute the resulting equations into Equation 13 to arrive at a single equation with only two unknown constants, $R_{s}$ and $z$ :

$$
\begin{aligned}
& \mathrm{i}=\left\{\mathrm{V}_{\mathrm{oc}} /\left\{\left[\left(\mathrm{i}_{\mathrm{sc}} * \mathrm{R}_{\mathrm{s}}-\mathrm{V}_{\mathrm{oc}}\right) *\left(\mathrm{e}^{\left(\mathrm{V}_{\mathrm{oc}} / \mathrm{z}\right)}-\mathrm{e}^{\left[\left(\mathrm{V}_{\mathrm{mp}}+\mathrm{I}_{\mathrm{mp}} * \mathrm{R}_{\mathrm{s}}\right) / \mathrm{z}\right]}\right)+\left(\mathrm{V}_{\mathrm{oc}}-\mathrm{V}_{\mathrm{mp}}-\mathrm{i}_{\mathrm{mp}} * \mathrm{R}_{\mathrm{s}}\right) *\right.\right.\right. \\
& \left.\left(\mathrm{e}^{\left(\mathrm{V}_{\text {oc }} / \mathrm{z}\right)}-\mathrm{e}^{\left(\mathrm{i}_{\mathrm{sc}} * \mathrm{R}_{\mathrm{s}} / \mathrm{z}\right)}\right)\right] /\left[\mathrm{i}_{\mathrm{mp}} *\left(\mathrm{e}^{\left(\mathrm{V}_{\mathrm{oc}} / \mathrm{z}\right)}-\mathrm{e}^{\left(\mathrm{i}_{\mathrm{sc}} * \mathrm{R}_{\mathrm{s}} / \mathrm{z}\right)}\right)+\right. \\
& \left.\left.\left.\mathrm{i}_{\mathrm{sc}} *\left(\mathrm{e}^{\left[\left(\mathrm{V}_{\mathrm{mp}}+\mathrm{I}_{\mathrm{mp}} * \mathrm{R}_{\mathrm{s}}\right) / \mathrm{z}\right]}-\mathrm{e}^{\left(\mathrm{V}_{\mathrm{oc}} / \mathrm{z}\right)}\right)\right]\right\}+\mathrm{I}_{\mathrm{o}} *\left(\mathrm{e}^{\mathrm{V}_{\mathrm{oc}} / \mathrm{z}}-1\right)\right\}- \\
& \left\{\mathrm { i } _ { \mathrm { sc } } * \left\{\left[\left(\mathrm{i}_{\mathrm{sc}} * \mathrm{R}_{\mathrm{s}}-\mathrm{V}_{\mathrm{oc}}\right) *\left(\mathrm{e}^{\left(\mathrm{V}_{\mathrm{oc}} / \mathrm{z}\right)}-\mathrm{e}^{\left[\left(\mathrm{V}_{\mathrm{mp}}+\mathrm{I}_{\mathrm{mp}} * \mathrm{R}_{\mathrm{s}}\right) / \mathrm{z}\right]}\right)+\left(\mathrm{V}_{\mathrm{oc}}-\mathrm{V}_{\mathrm{mp}}-\mathrm{i}_{\mathrm{mp}} * \mathrm{R}_{\mathrm{s}}\right) *\right.\right.\right. \\
& \left.\left(\mathrm{e}^{\left(\mathrm{V}_{\mathrm{oc}} / \mathrm{z}\right)}-\mathrm{e}^{\left(\mathrm{i}_{\mathrm{sc}} * \mathrm{R}_{\mathrm{s}} / \mathrm{z}\right)}\right)\right] /\left[\mathrm{i}_{\mathrm{mp}} *\left(\mathrm{e}^{\left(\mathrm{V}_{\mathrm{oc}} / \mathrm{z}\right)}-\mathrm{e}^{\left(\mathrm{i}_{\mathrm{sc}} * \mathrm{R}_{\mathrm{s}} / \mathrm{z}\right)}\right)+\mathrm{i}_{\mathrm{sc}} *\right. \\
& \left.\left.\left.\left(\mathrm{e}^{\left[\left(\mathrm{V}_{\mathrm{mp}}+\mathrm{I}_{\mathrm{mp}} * \mathrm{R}_{\mathrm{s}}\right) / \mathrm{z}\right]}-\mathrm{e}^{\left(\mathrm{V}_{\mathrm{oc}} / \mathrm{z}\right)}\right)\right]\right\}+\mathrm{i}_{\mathrm{sc}} * \mathrm{R}_{\mathrm{s}}-\mathrm{V}_{\mathrm{oc}}\right\} / \\
& \left\{\left[\left(\mathrm{i}_{\mathrm{sc}} * \mathrm{R}_{\mathrm{s}}-\mathrm{V}_{\mathrm{oc}}\right) *\left(\mathrm{e}^{\left(\mathrm{V}_{\mathrm{oc}} / \mathrm{z}\right)}-\mathrm{e}^{\left[\left(\mathrm{V}_{\mathrm{mp}}+\mathrm{I}_{\mathrm{mp}} * \mathrm{R}_{\mathrm{s}}\right) / \mathrm{z}\right]}\right)+\left(\mathrm{V}_{\mathrm{oc}}-\mathrm{V}_{\mathrm{mp}}-\mathrm{i}_{\mathrm{mp}} * \mathrm{R}_{\mathrm{s}}\right) *\right.\right. \\
& \left.\left(\mathrm{e}^{\left(\mathrm{V}_{\mathrm{oc}} / \mathrm{z}\right)}-\mathrm{e}^{\left(\mathrm{i}_{\mathrm{sc}} * \mathrm{R}_{\mathrm{s}} / \mathrm{z}\right)}\right)\right] /\left[\mathrm{i}_{\mathrm{mp}} *\left(\mathrm{e}^{\left(\mathrm{V}_{\mathrm{oc}} / \mathrm{z}\right)}-\mathrm{e}^{\left(\mathrm{i}_{\mathrm{sc}} * \mathrm{R}_{\mathrm{s}} / \mathrm{z}\right)}\right)+\mathrm{i}_{\mathrm{sc}} *\right. \\
& \left.\left.\left.\left(\mathrm{e}^{\left[\left(\mathrm{V}_{\mathrm{mp}}+\mathrm{I}_{\mathrm{mp}} * \mathrm{R}_{\mathrm{s}}\right) / \mathrm{z}\right]}-\mathrm{e}^{\left(\mathrm{V}_{\mathrm{oc}} / \mathrm{z}\right)}\right)\right]\right\} /\left(\mathrm{e}^{\left(\mathrm{V}_{\text {oc }} / \mathrm{z}\right)}-\mathrm{e}^{\left(\mathrm{I}_{\mathrm{sc}} * \mathrm{R}_{\mathrm{s}} / \mathrm{z}\right)}\right)\right\} * \\
& \left(\mathrm{e}^{[(\mathrm{V}+\mathrm{i} * \mathrm{Rs}) / \mathrm{z}]}-1\right)- \\
& \left\{\left(\mathrm{V}+\mathrm{i} * \mathrm{R}_{\mathrm{s}}\right) /\right. \\
& \left\{\left[\left(\mathrm{i}_{\mathrm{sc}} * \mathrm{R}_{\mathrm{s}}-\mathrm{V}_{\mathrm{oc}}\right) *\left(\mathrm{e}^{\left(\mathrm{V}_{\mathrm{oc}} / \mathrm{z}\right)}-\mathrm{e}^{\left[\left(\mathrm{V}_{\mathrm{mp}}+\mathrm{I}_{\mathrm{mp}} * \mathrm{R}_{\mathrm{s}}\right) / \mathrm{z}\right]}\right)+\right.\right. \\
& \left.\left(\mathrm{V}_{\mathrm{oc}}-\mathrm{V}_{\mathrm{mp}}-\mathrm{i}_{\mathrm{mp}} * \mathrm{R}_{\mathrm{s}}\right) *\left(\mathrm{e}^{\left(\mathrm{V}_{\mathrm{oc}} / \mathrm{z}\right)}-\mathrm{e}^{\left(\mathrm{i}_{\mathrm{sc}} * \mathrm{R}_{\mathrm{s}} / \mathrm{z}\right)}\right)\right] / \\
& \left.\left.\left[\mathrm{i}_{\mathrm{mp}} *\left(\mathrm{e}^{\left(\mathrm{V}_{\mathrm{oc}} / \mathrm{z}\right)}-\mathrm{e}^{\left(\mathrm{i}_{\mathrm{sc}} * \mathrm{R}_{\mathrm{s}} / \mathrm{z}\right)}\right)+\mathrm{i}_{\mathrm{sc}} *\left(\mathrm{e}^{\left[\left(\mathrm{V}_{\mathrm{mp}}+\mathrm{I}_{\mathrm{mp}} * \mathrm{R}_{\mathrm{s}}\right) / \mathrm{z}\right]}-\mathrm{e}^{\left(\mathrm{V}_{\mathrm{oc}} / \mathrm{z}\right)}\right)\right]\right\}\right\} \text {. }
\end{aligned}
$$

Because we have imposed the restrictions that $i=0$ at $V=V_{o c}, V=0$ at $i=i_{s c}$, and $i=i_{m p}$ at $V=$ $V_{m p}$, the curve described by Equation 17 will always pass through these three points on the I-V curve. The constants $R_{s}$ and $z$ are adjusted to obtain the best fit through the two remaining points 
$\left(i_{x}, V_{x}\right.$ and $i_{x x}, V_{x x}$ ) predicted by equations 5 and 7 . The adjustment of $R_{s}$ and $z$ is made by minimizing the RMS error between the measured and the calculated values of $i_{x}$ and $i_{x x}$ :

$$
E_{\text {rms }}=\left\{\left[\left(i_{x, \text { meas }}-i_{x, \text { calc }}\right)^{2}+\left(i_{x x, \text { meas }}-i_{x x, \text { calc }}\right)^{2}\right] / 2\right\}^{1 / 2}
$$

We have performed the minimization of $\mathrm{E}_{\mathrm{rms}}$ using a routine employing the "Downhill Simplex Method" from Numerical Recipes [12]. We have found that the minimization tends to be quite unstable when using Equation 17, largely because of its implicit nature (the equation can not be explicitly solved for $i$ ). To stabilize the minimization we substitute $i_{\text {TRW }}$ from Equation 10 for $i$ on the right side of Equation 17:

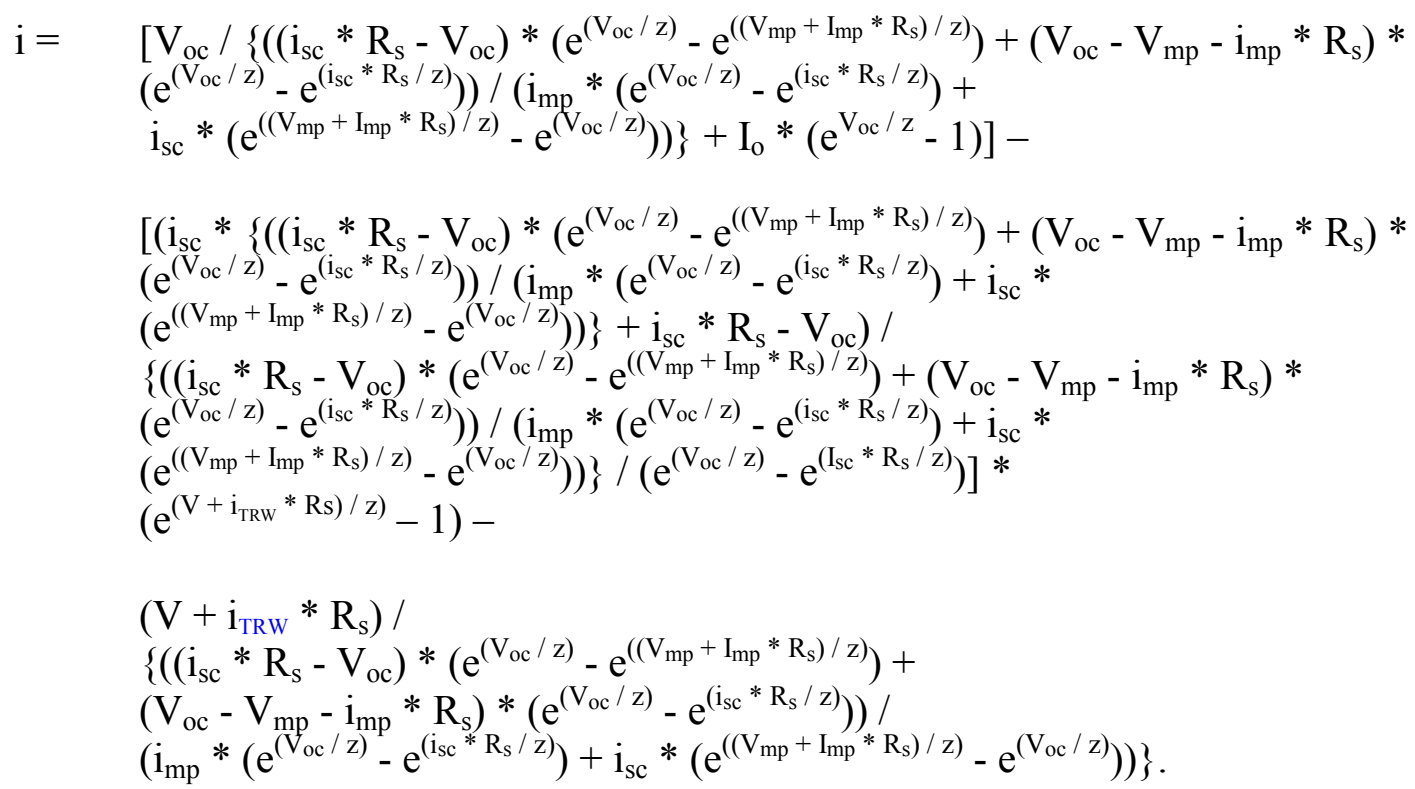

Because Equation 10 already predicts $i$ closely, and $i$ only appears on the right side of Equation 17 as part of the product $\left(i^{*} R_{S}\right)$, the adjustment of $R_{S}$ tends to make up for slight errors in $i_{T R W}$. The two $i_{T R W}$ terms have been colored blue in Equation 19 above to highlight their positions. Figure 4 shows an example of measured data compared to the curves generated by Equation 10 and Equation 19. Occasionally the minimization routine is unsuccessful in converging on a set of $R_{s}$ and $z$ that provide a better $E_{r m s}$ than Equation 10; in these rare cases we have reverted to simply using Equation 10 to predict $i$ as a function of $V$.

It should be noted that equations 17 and 19 are particularly cumbersome; in fact, we have typically solved for $i$ as a function of $V, R_{s}$, and $z$ in 4 steps:

(1) Solve for $R_{s h}$ using $R_{s}, z$, and Equation 16

(2) Solve for $i_{0}$ using $R_{s h}$ and Equation 15

(3) Solve for $i_{L}$ using $R_{s h}, i_{0}$, and Equation 14

(4) Solve for $i$ using $R_{s h}, i_{0}, i_{L}$, and Equation 13, and substituting $i_{T R W}$ for $i$ on the right-hand side of Equation 13. 


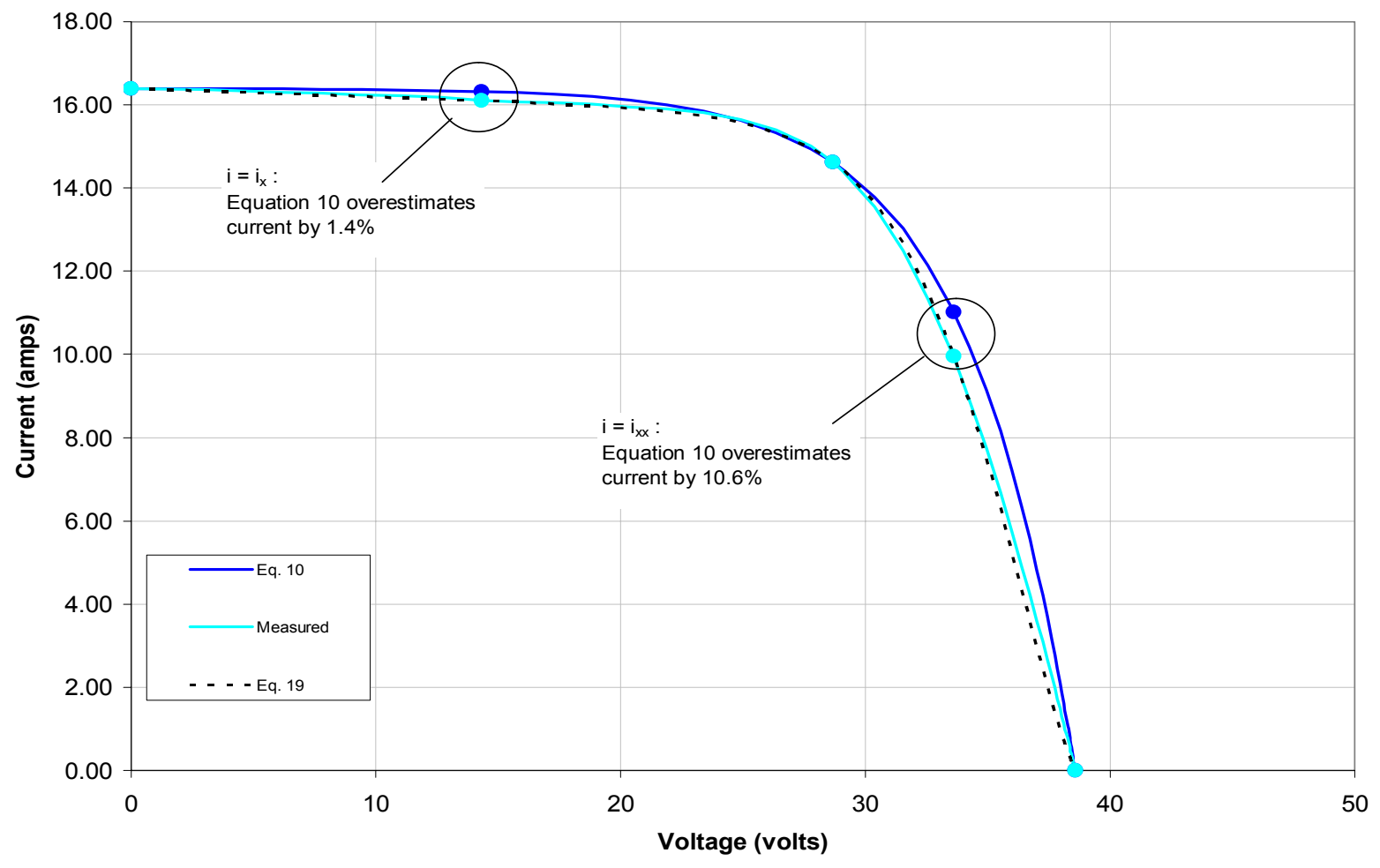

Figure 4. Example I-V curve showing the five points defined by equations 4 through 9. The TRW equation (Equation 10) tends to overestimate the current on both sides of the maximum power point. Equation 19 fits the measured data quite well.

\section{3b.5. Predicting Module Temperature}

During in-situ testing, it is typically reasonable to measure the temperature of the back of one or more modules in the array. It is usually not realistic to try to measure the actual cell temperature, as this would involve a delicate operation on the back of the module to expose the cells, and this destroys the integrity of the weatherproof seal as well as increasing the risk of harming the module. King [6] and King et al. [7] measured cell and back-of-module temperature for their database of PV modules and found that, for a rack-mounted collector, the cell temperature is typically $2-3^{\circ} \mathrm{C}$ higher than the back-of-module temperature under Standard Rating Conditions. In fact, we need not be concerned with the actual cell temperature in order to calibrate a model for the in-situ array; we propose that all fits be made in respect to the back-of-module temperature.

Predicting the module temperature as a function of outdoor conditions has been the subject of numerous papers, among them King [6] and King et al. [7], Del Cueto et al. [13], Jones et al. [14], Davis et al. [15], and Ingersoll [16]. King [6] and King et al. [7] proposed the following equation for predicting the module temperature:

$$
\mathrm{T}_{\text {mod }}=\mathrm{I}_{\mathrm{c}}\left(\mathrm{e}^{\left(\mathrm{a}+\mathrm{b}^{*} \mathrm{~V}_{\mathrm{w}}\right)}\right)+\mathrm{T}_{\mathrm{a}}
$$


where $\mathrm{a}$ and $\mathrm{b}$ are module-specific constants provided in the Sandia database. Equation 20 is expected to be reasonably accurate for rack-mounted collectors under medium to high insolation with good ventilation on the front and back. The module temperature is highly dependent on the mounting configuration, however. For building-integrated photovoltaics, for example, when the modules may be glued to an insulated roof, we have observed the module temperature to be on the order of $15^{\circ} \mathrm{C}$ higher than the equivalent module on a rack mount. Because of the strong dependence on the mounting geometry, we have typically used the approach presented by Ingersoll [16], which gives methods for estimating module temperature for four different mounting schemes: rack-mount, standoff-mount, direct-mount, and integral mount. The four mounting schemes are illustrated in Figure 5.

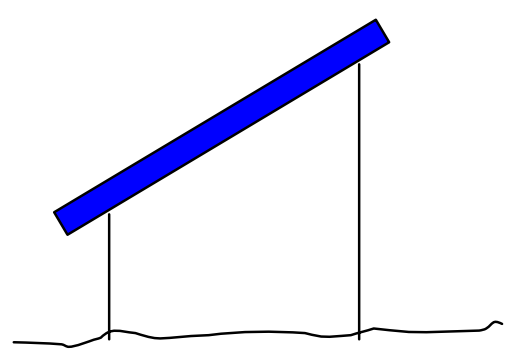

(a) rack-mount

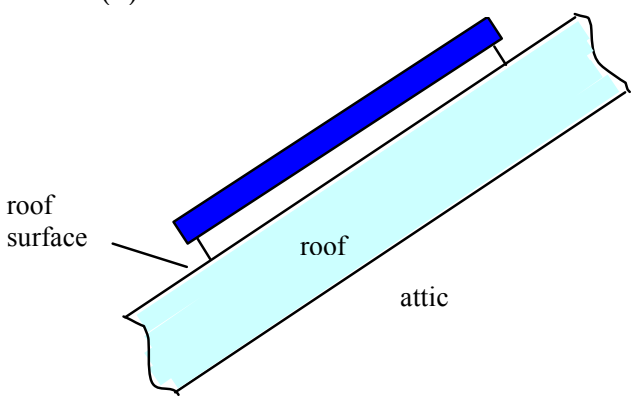

(b) standoff-mount

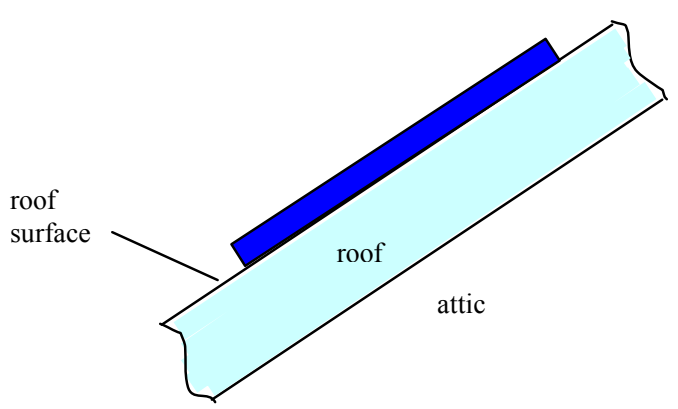

(c) direct-mount

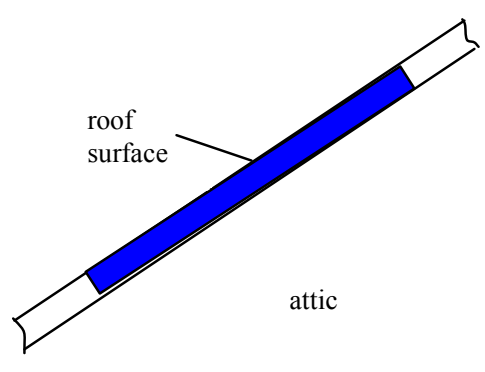

(d) integral-mount

Figure 5. Four typical mounting schemes for PV arrays, resulting in different module temperatures under the same environmental conditions. 
Ingersoll proposed a general equation form for calculating $T_{c}$ :

$$
\mathrm{T}_{\mathrm{c}}=\frac{(\tau \alpha) \mathrm{I}_{\mathrm{c}}-\eta_{\mathrm{o}} \mathrm{I}_{\mathrm{c}}+\mathrm{T}_{\mathrm{a}}\left[\mathrm{h}_{\mathrm{cf}}+2 \sigma \varepsilon_{\mathrm{c}} \tau_{\mathrm{RR}}(1+\cos \beta) \mathrm{T}_{\mathrm{sky}} \mathrm{T}_{\mathrm{a}}{ }^{2}+\mathrm{h}_{\mathrm{cb}}+4 \sigma \mathrm{T}_{\mathrm{a}}{ }^{3} \mathrm{~F}_{\mathrm{e}} \mathrm{F}_{\mathrm{b}}\right]}{\mathrm{h}_{\mathrm{cf}}+2 \sigma \varepsilon_{\mathrm{c}} \tau_{\mathrm{IR}} \mathrm{T}_{\mathrm{a}}{ }^{3}(1+\cos \beta)+\mathrm{h}_{\mathrm{cb}}+4 \sigma \mathrm{T}_{\mathrm{a}}{ }^{3} \mathrm{~F}_{\mathrm{e}} \mathrm{F}_{\mathrm{b}}}
$$

and supplied Table 1 for the calculation of $h_{c b}, F_{e}$, and $F_{\mathrm{b}}$. When the heat loss from the back of the array is zero, the maximum possible cell temperature is reached:

$$
\mathrm{T}_{\mathrm{c}, \max }=\frac{(\tau \alpha) \mathrm{I}_{\mathrm{c}}-\eta_{\mathrm{o}} \mathrm{I}_{\mathrm{c}}+\mathrm{T}_{\mathrm{a}}\left[\mathrm{h}_{\mathrm{cf}}+2 \sigma \varepsilon_{\mathrm{c}} \tau_{\mathrm{IR}}(1+\cos \beta) \mathrm{T}_{\text {sky }} \mathrm{T}_{\mathrm{a}}^{2}\right]}{\mathrm{h}_{\mathrm{cf}}+2 \sigma \varepsilon_{\mathrm{c}} \tau_{\mathrm{IR}} \mathrm{T}_{\mathrm{a}}{ }^{3}(1+\cos \beta) .}
$$

Equation 21 is a non-linear equation; $T_{c}$ must be known to estimate $h_{c b}$ for all but the rack-mount case. Ingersoll noted that using $T_{c, \max }$ as an estimate of $T_{c}$ in calculating $h_{c b}$ worked quite well; alternatively, an iterative solution to Equation 21 can be employed.

The back-of-module temperature, $T_{m o d}$, is assumed to approximately equal to $T_{c}$ in the derivation of Equation 22. This is a reasonable assumption for typical PV modules in prediction of $T_{\text {mod }}$ for annual simulation.

$T_{\text {sky }}$ can be estimated using equations 23 and 24 [17]:

$$
\begin{aligned}
& \varepsilon_{\text {sky }}=0.711+0.005 \mathrm{~T}_{\mathrm{dp}}+7.3 \mathrm{X} 10^{-5} \mathrm{~T}_{\mathrm{dp}}{ }^{2}+0.013 \operatorname{Cos}\left(2 \pi \mathrm{t}_{\mathrm{LST}} / 24\right)+0.12\left(\mathrm{P}_{\mathrm{atm}}-101.4\right) \\
& \mathrm{T}_{\text {sky }}=\left(\left(\mathrm{T}_{\mathrm{a}}+273.15\right)\left(\varepsilon_{\text {sky }}+0.8 \mathrm{~F}_{\text {cc }}\left(1-\varepsilon_{\text {sky }}\right)\right)^{0.25}\right)-273.15 .
\end{aligned}
$$

If no measurement or observation of $F_{c c}$ is available, it can be estimated using an equation from Kasten and Czeplak [18]:

$$
\mathrm{F}_{\mathrm{cc}}=\left(1.4286 * \mathrm{I}_{\mathrm{dh}} / \mathrm{I}_{\mathrm{h}}-0.3\right){ }^{0.5}
$$

\section{3b.6. Predicting Annual Performance}

We have written a module for TRNSYS for predicting PV array output given the results of a day-long test. Driven by TMY2 weather data, TRNSYS is used to calculate all weather parameters (beam and diffuse insolation, dry-bulb temperature, dewpoint, sky temperature, wind speed). For each simulation time step (typically 15 -minute), a Power-Voltage curve is generated using equations 1, 2, 4, 5, 6, 7, 8, and 9 and the procedure described in Section 4. Equation 21 is used to predict module temperature. For each time step, then, the power output of the array can be predicted at any voltage.

Typically, we report the maximum possible power output $\left(V=V_{m p}\right)$ and the actual expected output. In our field tests to date, most systems have either not employed a MPPT device or the MPPT has not operated properly. In typical battery-storage systems, the voltage across the array is equal to the voltage across the battery bank. In these cases, TRNSYS is used to simulate the battery voltage for each time step; this voltage is used to calculate the PV array output for this time step. We have encountered more than one system where the battery voltage is not wellmatched with the PV array; the battery voltage is well off of $V_{m p}$, resulting in lower power output than would be expected if good maximum power point tracking were employed. 
Table 1. Convective and Radiative Heat Transfer Parameters for Back of Array

\begin{tabular}{|c|c|c|c|}
\hline Mounting Type & $\begin{array}{c}\text { Convective Heat Transfer } \\
\text { Coefficient }\left(\mathrm{h}_{\mathrm{cb}}\right) \\
\left(\mathrm{W} / \mathrm{m}^{2}-{ }^{\circ} \mathrm{C}\right)\end{array}$ & $\begin{array}{l}\text { Back Panel Surface } \\
\text { Emissivity Factor } \\
\left(F_{\mathrm{e}}\right)\end{array}$ & $\begin{array}{l}\text { Back Panel Surface } \\
\text { Configuration } \\
\text { Factor }\left(F_{b}\right)\end{array}$ \\
\hline Rack & $\begin{array}{l}V_{w}<0.45 \mathrm{~m} / \mathrm{s}: \\
\mathrm{h}_{\mathrm{cb}}=5.0 \\
V_{w} \pm 0.45 \mathrm{~m} / \mathrm{s}: \\
\mathrm{h}_{\mathrm{cb}}=0.6+6.64 \mathrm{~V}_{\mathrm{w}}^{0.5}\end{array}$ & $\mathrm{~F}_{\mathrm{e}}=\varepsilon_{\mathrm{b}}$ & $F_{b}=(1-\cos \beta) / 2$ \\
\hline Standoff $* *$ & $\begin{array}{l}G r^{*}<2 X 10^{7} \text { (laminar): } \\
\mathrm{h}_{\mathrm{cb}}=1.016(\Delta \mathrm{T} \sin \beta / \mathrm{L})^{1 / 4}(\mathrm{~d} / \mathrm{L})^{1 / 9} \\
G r^{*}>2 X 10^{7}(\text { turbulent }): \\
\mathrm{h}_{\mathrm{cb}}=1.795(\Delta \mathrm{T} \sin \beta)^{1 / 3}(\mathrm{~b} / \mathrm{L})^{1 / 9}\end{array}$ & $\mathrm{~F}_{\mathrm{e}}=\varepsilon_{\mathrm{b}} \varepsilon_{\mathrm{r}} /\left(\varepsilon_{\mathrm{b}}+\varepsilon_{\mathrm{r}}-\varepsilon_{\mathrm{b}} \varepsilon_{\mathrm{r}}\right)$ & $F_{b}=1.0$ \\
\hline Direct **** & $\begin{array}{l}\left.G r^{*}<2 X 10^{7} \text { (laminar }\right): \\
\mathrm{h}_{\mathrm{ri}}=2.455(\Delta \mathrm{T} \sin \beta / \mathrm{L})^{1 / 4} \\
G r^{*}>2 X 10^{7}(\text { turbulent }): \\
\mathrm{h}_{\mathrm{ri}}=1.725(\Delta \mathrm{T} \sin \beta)^{1 / 3} \\
\mathrm{~h}_{\mathrm{cb}}=\mathrm{U}_{\mathrm{r}} \mathrm{h}_{\mathrm{ri}}\left(\mathrm{U}_{\mathrm{c}}+\mathrm{h}_{\mathrm{ri}}\right)\end{array}$ & $\mathrm{F}_{\mathrm{e}}=\varepsilon_{\mathrm{a}} \varepsilon_{\mathrm{ri}}$ & $F_{b}=1.0$ \\
\hline $\begin{array}{l}\text { Integral with } \\
\text { Natural Attic } \\
\text { Ventilation *** }\end{array}$ & $\begin{array}{l}\left.G r^{*}<2 X 10^{7} \text { (laminar }\right): \\
\mathrm{h}_{\mathrm{cb}}=2.455(\Delta \mathrm{T} \sin \beta / \mathrm{L})^{1 / 4} \\
G r^{*}>2 X 10^{7}(\text { turbulent }): \\
\mathrm{h}_{\mathrm{cb}}=1.725(\Delta \mathrm{T} \sin \beta)^{1 / 3}\end{array}$ & $F_{e}=\varepsilon_{b} \varepsilon_{a}$ & $F_{b}=1.0$ \\
\hline
\end{tabular}

* $\quad \mathrm{Gr}=120 \times 10^{6} \Delta \mathrm{T} \sin \beta L^{3}$

** $\Delta \mathrm{T}=\mathrm{T}_{\mathrm{c}}-\mathrm{T}_{\mathrm{a}}$

*** $\quad \Delta \mathrm{T}=\left(\mathrm{T}_{\mathrm{c}}-\mathrm{T}_{\mathrm{a}}\right) / 2$

$* * * * \quad \Delta \mathrm{T}=\mathrm{T}_{\mathrm{c}}-0.5\left(\mathrm{~T}_{\mathrm{c}}-\mathrm{T}_{\mathrm{a}}\right)\left(1+\mathrm{U}_{\mathrm{c}} /\left(\mathrm{U}_{\mathrm{c}}+\mathrm{h}_{\mathrm{r}}\right)\right)$ 


\section{3b.7. Generalizing for Module Types Not in the Sandia Database}

Although the Sandia database includes more than 100 module types, it is not uncommon to test an array of modules not in the database. In this case the coefficients for $M_{A m a}$ and $M_{\theta i}$ are not known (equations 1 and 2). Figures 1 and 2 show that, if there is some knowledge of the cell and glazing materials, a reasonable estimate of the coefficients can be made. $\mathrm{M}_{\mathrm{Ama}}$ is largely a cell material effect; we condensed Figure 1 into 8 categories:

(1) Monocrystalline Silicon (c-Si)

(2) Multicrystalline Silicon (mc-Si)

(3) 2-Junction Amorphous Silicon (2-a-Si)

(4) 3-Junction Amorphous Silicon (3-a-Si)

(5) EFG Multicrystalline Silicon (EFG mc-Si)

(6) Copper Indium Diselenide (CIS)

(7) Cadmium Telluride (CdTe)

(8) Multicrystalline Silicon Film.

The coefficients for Equation 1 are given in Table 2 for each of the eight cell material categories. Similarly, incident angle behavior can be generalized into three glazing categories:

(1) Smooth Glass

(2) Smooth Glass with Anti-Reflective Coating on Cells

(3) Dimpled Tefzel.

The coefficients for Equation 2 are given in Table 3 for each of the three glazing categories.

Finally, sometimes the temperature coefficients $\alpha_{i s c}, \beta_{V o c}, \alpha_{i m p}, \beta_{V m p}, \alpha_{i x}$, and $\alpha_{i x x}$ are difficult to determine from a day-long test of an array, particularly the temperature coefficients of current, which are usually very small. When a coefficient is not well-determined from a data set using equations 4 through 9, we would like to refer to the manufacturer's data. Coefficients $\alpha_{i m p}, \beta_{V m p}$, $\alpha_{i x}$, and $\alpha_{i x x}$ are typically not provided by the manufacturer, although usually $\alpha_{i s c}$ and $\beta_{V o c}$ are provided. Again referring to the Sandia database of coefficients for different modules, we can predict $\alpha_{i m p}, \beta_{V m p}, \alpha_{i x}, \alpha_{i x x}$ for a module whose coefficients $\alpha_{i s c}$ and $\beta_{V o c}$ are known. We have defined the coefficients $r_{\alpha}$ and $r_{\beta}$ such that:

$$
\begin{array}{lll}
\alpha_{\mathrm{imp}} & = & \mathrm{r}_{\alpha} \alpha_{\mathrm{isc}} \\
\beta_{\mathrm{Vmp}} & = & \mathrm{r}_{\beta} \beta_{\mathrm{Vmp} .}
\end{array}
$$

By reviewing the Sandia database, we found that the ratios $r_{\alpha}$ and $\mathrm{r}_{\beta}$ are more generalizable by cell material than $\alpha_{\mathrm{imp}}$ and $\beta_{\mathrm{Vmp}}$. Figure 6 shows $r_{\alpha}$ and $r_{\beta}$ for all modules in the Sandia database. In Table 4 we give the average values of $r_{\alpha}$ and $r_{\beta}$ for 8 different cell material categories. 
King [1997] recommended the following equations for estimating $\alpha_{i x}$ and $\alpha_{i x x}$ :

$\begin{array}{lll}\alpha_{\mathrm{ix}} & = & 0.5\left(\alpha_{\mathrm{isc}}+\alpha_{\mathrm{imp}}\right) \\ \alpha_{\mathrm{ixx}} & = & \alpha_{\mathrm{imp}} .\end{array}$

Table 2. $M_{\text {Ama }}$ Coefficients for Eight Cell Materials

\begin{tabular}{lccccc}
\hline \multicolumn{1}{c}{ Cell Material } & $\mathbf{a}_{0}$ & $\mathbf{a}_{1}$ & $\mathbf{a}_{2}$ & $\mathbf{a}_{3}$ & $\mathbf{a}_{4}$ \\
\hline $\begin{array}{l}\text { Monocrystalline Silicon } \\
\text { (c-Si) }\end{array}$ & 1.007493 & $-2.18335 \mathrm{E}-02$ & $1.68364 \mathrm{E}-02$ & $-2.61715 \mathrm{E}-03$ & $1.21716 \mathrm{E}-04$ \\
$\begin{array}{l}\text { Multicrystalline Silicon } \\
\text { (mc-Si) }\end{array}$ & 1.002933 & $-1.38577 \mathrm{E}-02$ & $1.30445 \mathrm{E}-02$ & $-2.23131 \mathrm{E}-03$ & $1.11179 \mathrm{E}-04$ \\
$\begin{array}{l}\text { 2-Junction Amorphous } \\
\text { Silicon (2-a-Si) }\end{array}$ & 0.956028 & $7.80442 \mathrm{E}-02$ & $-3.75356 \mathrm{E}-02$ & $3.56222 \mathrm{E}-03$ & $-9.91272 \mathrm{E}-05$ \\
$\begin{array}{l}\text { 3-Junction Amorphous } \\
\text { Silicon (3-a-Si) }\end{array}$ & 0.947585 & $1.04304 \mathrm{E}-01$ & $-5.88808 \mathrm{E}-02$ & $7.27597 \mathrm{E}-03$ & $-2.84873 \mathrm{E}-04$ \\
$\begin{array}{l}\text { EFG Multicrystalline } \\
\text { Silicon (EFG mc-Si) }\end{array}$ & 1.006921 & $-2.02301 \mathrm{E}-02$ & $1.56043 \mathrm{E}-02$ & $-2.40634 \mathrm{E}-03$ & $1.11512 \mathrm{E}-04$ \\
$\begin{array}{l}\text { Copper Indium } \\
\text { Diselenide (CIS) }\end{array}$ & 1.002934 & $-1.34724 \mathrm{E}-02$ & $1.25627 \mathrm{E}-02$ & $-2.13104 \mathrm{E}-03$ & $1.06505 \mathrm{E}-04$ \\
$\begin{array}{l}\text { Cadmium Telluride } \\
\text { (CdTe) }\end{array}$ & 1.002757 & $-1.50992 \mathrm{E}-02$ & $1.49883 \mathrm{E}-02$ & $-2.78758 \mathrm{E}-03$ & $1.41854 \mathrm{E}-04$ \\
$\begin{array}{l}\text { Multicrystalline Silicon } \\
\text { Film }\end{array}$ & 0.993985 & $4.45904 \mathrm{E}-03$ & $2.46337 \mathrm{E}-03$ & $-9.71569 \mathrm{E}-04$ & $6.46083 \mathrm{E}-05$ \\
\hline
\end{tabular}

Table 3. $M_{\theta i}$ Coefficients for Three Types of Glazings

\begin{tabular}{lcccccc}
\hline \multicolumn{1}{c}{ Glazing } & $\mathbf{b}_{\mathbf{0}}$ & $\mathbf{b}_{\mathbf{1}}$ & $\mathbf{b}_{\mathbf{2}}$ & $\mathbf{b}_{\mathbf{3}}$ & $\mathbf{b}_{\mathbf{4}}$ & $\mathbf{b}_{\mathbf{5}}$ \\
\hline $\begin{array}{l}\text { Smooth Glass } \\
\text { Smooth Glass / }\end{array}$ & 1.0 & $-3.3101 \mathrm{E}-03$ & $4.1289 \mathrm{E}-04$ & $-1.6280 \mathrm{E}-05$ & $2.6740 \mathrm{E}-07$ & $-1.6432 \mathrm{E}-09$ \\
$\begin{array}{l}\text { Anti-Reflective } \\
\text { Cells }\end{array}$ & & & & & & \\
Dimpled Tefzel & 1.0 & $-4.6445 \mathrm{E}-03$ & $5.8607 \mathrm{E}-04$ & $-2.3108 \mathrm{E}-05$ & $3.7843 \mathrm{E}-07$ & $-2.2515 \mathrm{E}-09$ \\
& 1.0 & $-4.5158 \mathrm{E}-03$ & $5.2488 \mathrm{E}-04$ & $-2.0791 \mathrm{E}-05$ & $3.5011 \mathrm{E}-07$ & $-2.1457 \mathrm{E}-09$ \\
\hline
\end{tabular}




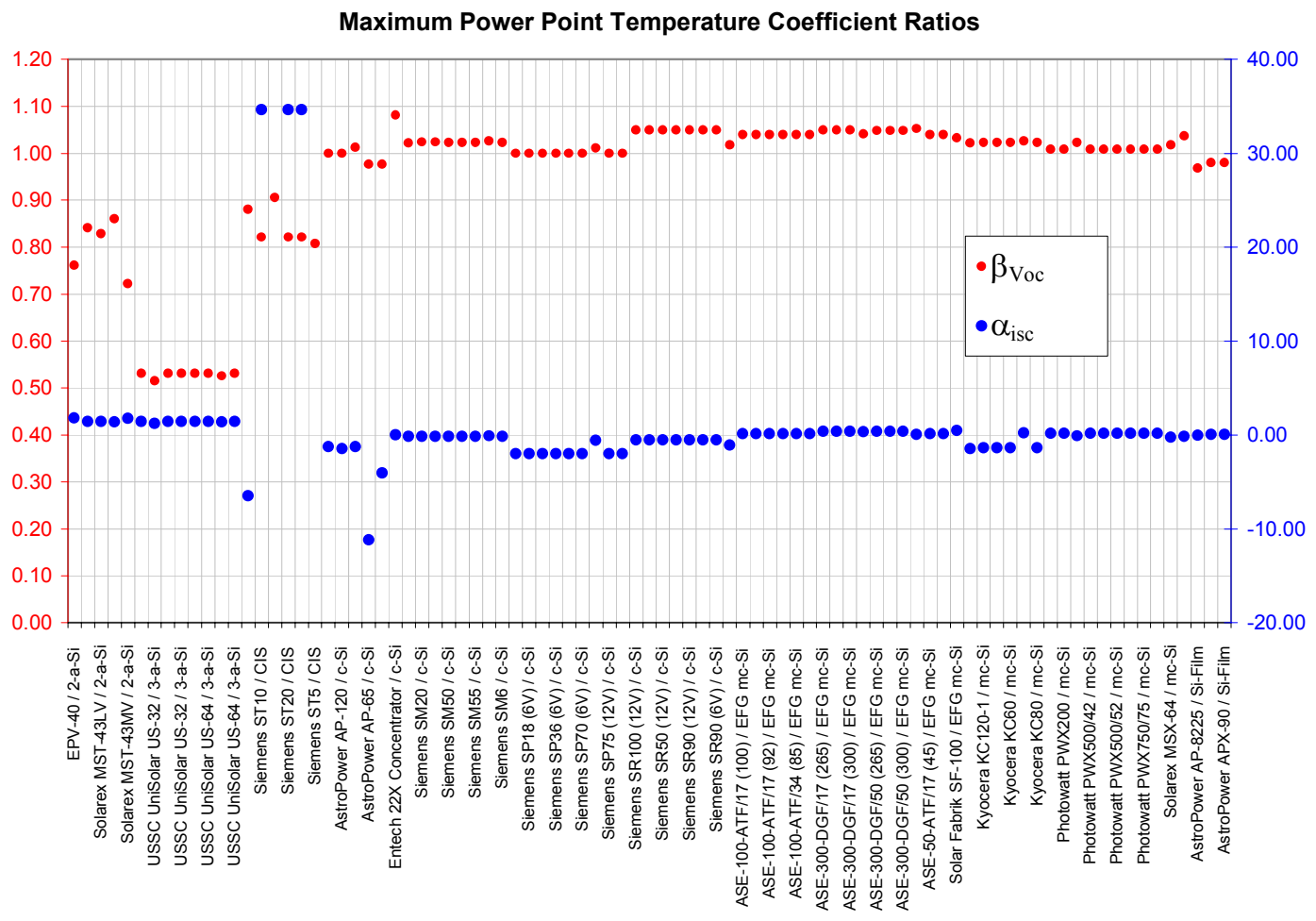

Figure 6. Ratio of $\beta_{\mathrm{Vmp}}$ to $\beta_{\mathrm{Voc}}$ (red) and $\alpha_{\mathrm{imp}}$ to $\alpha_{\text {isc }}$ (blue) from the Sandia database of module characteristics

Table 4. Temperature Coefficient Ratios $r_{\alpha}$ and $r_{\beta}$

\begin{tabular}{lcc}
\hline Cell Material & $\mathbf{r}_{\alpha}$ & $\mathbf{r}_{\beta}$ \\
\hline Monocrystalline Silicon (c-Si) & -1.349 & 1.019 \\
Multicrystalline Silicon (mc-Si) & -0.362 & 1.016 \\
2-Junction Amorphous Silicon (2-a-Si) & 1.566 & 0.802 \\
3-Junction Amorphous Silicon (3-a-Si) & 1.382 & 0.528 \\
EFG Multicrystalline Silicon (EFG mc-Si) & 0.247 & 1.043 \\
Copper Indium Diselenide (CIS) & 34.615 & 0.835 \\
Cadmium Telluride (CdTe) & -6.508 & 0.880 \\
Multicrystalline Silicon Film & 0.009 & 0.975 \\
\hline
\end{tabular}




\section{Example Application of the Analysis Method: A 630-Watt Nominal Rack-Mounted Array}

As an example of implementing the technique described in this paper, we present below the results of a short-term test on a rack-mounted PV array in Golden, Colorado. The test was performed from 11:00 a.m. to 5:00 p.m. on June 28, 2001; the array is described in Table 5.

The type of module in this array can be found in the Sandia database; therefore, coefficients for Equation 1 and Equation 2 were taken from there. These coefficients are shown in tables 6 and 7.

A total of $24 \mathrm{I}-\mathrm{V}$ traces were made, one every 15 minutes. The P-V curves are shown in Figure 7.

For these curve traces, the incident radiation ambient temperature and back-of-module temperature are shown in Figure 8. Also shown is the Effective Radiation $\left(\mathrm{I}_{\mathrm{c}, \mathrm{eff}}\right)$ calculated by applying equations 1 and 2 .

Table 5. Description of Tested Array

\begin{tabular}{ll}
\hline Module Type & Seimens SM55, monocrystalline silicon \\
\hline Number of modules in series per string & 2 \\
Number of strings & 6 \\
Array Slope & 40 degrees from horizontal \\
Array Azimuth & due south \\
Array nominal rating & 631.5 Watts \\
\hline
\end{tabular}

Table 6. Coefficients for Equation 1, taken from Sandia Database for Seimens SM55 PV Module

\begin{tabular}{ccccc}
\hline a0 & a1 & a2 & a3 & a4 \\
\hline 0.938 & 0.054228 & -0.0099 & 0.00073 & $-1.9 \mathrm{E}-05$ \\
\hline
\end{tabular}

Table 7. Coefficients for Equation 2, taken from Sandia Database for Seimens SM55 PV Module

\begin{tabular}{cccccc}
\hline b0 & b1 & b2 & b3 & b4 & b5 \\
\hline 1.000 & -0.00244 & 0.00031 & $-1.2 \mathrm{E}-05$ & $2.11 \mathrm{E}-07$ & $-1.4 \mathrm{E}-09$ \\
\hline
\end{tabular}




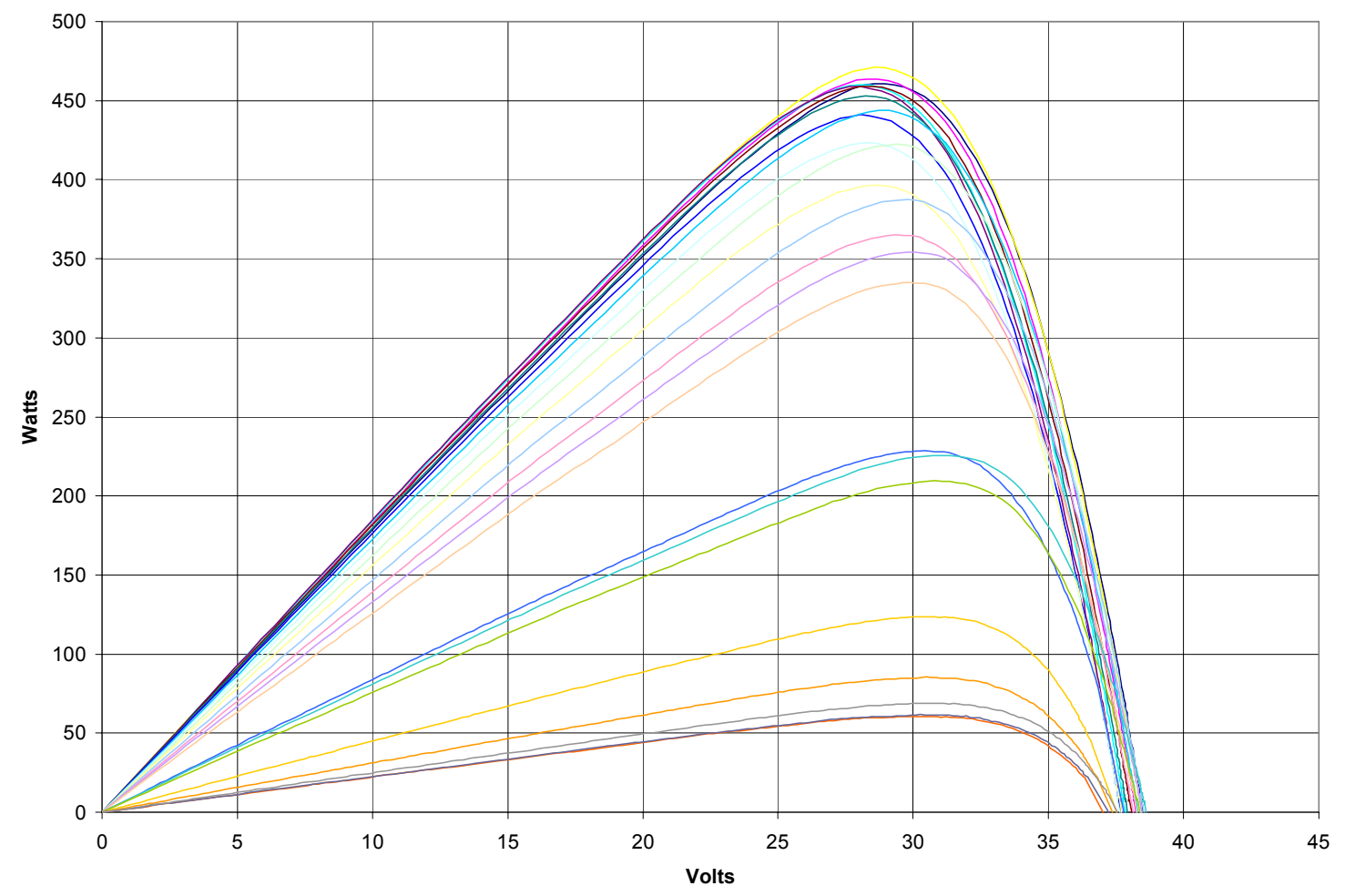

Figure 7. Power-Voltage curves taken every 15 minutes from 11:00 a.m. to 5:00 p.m.

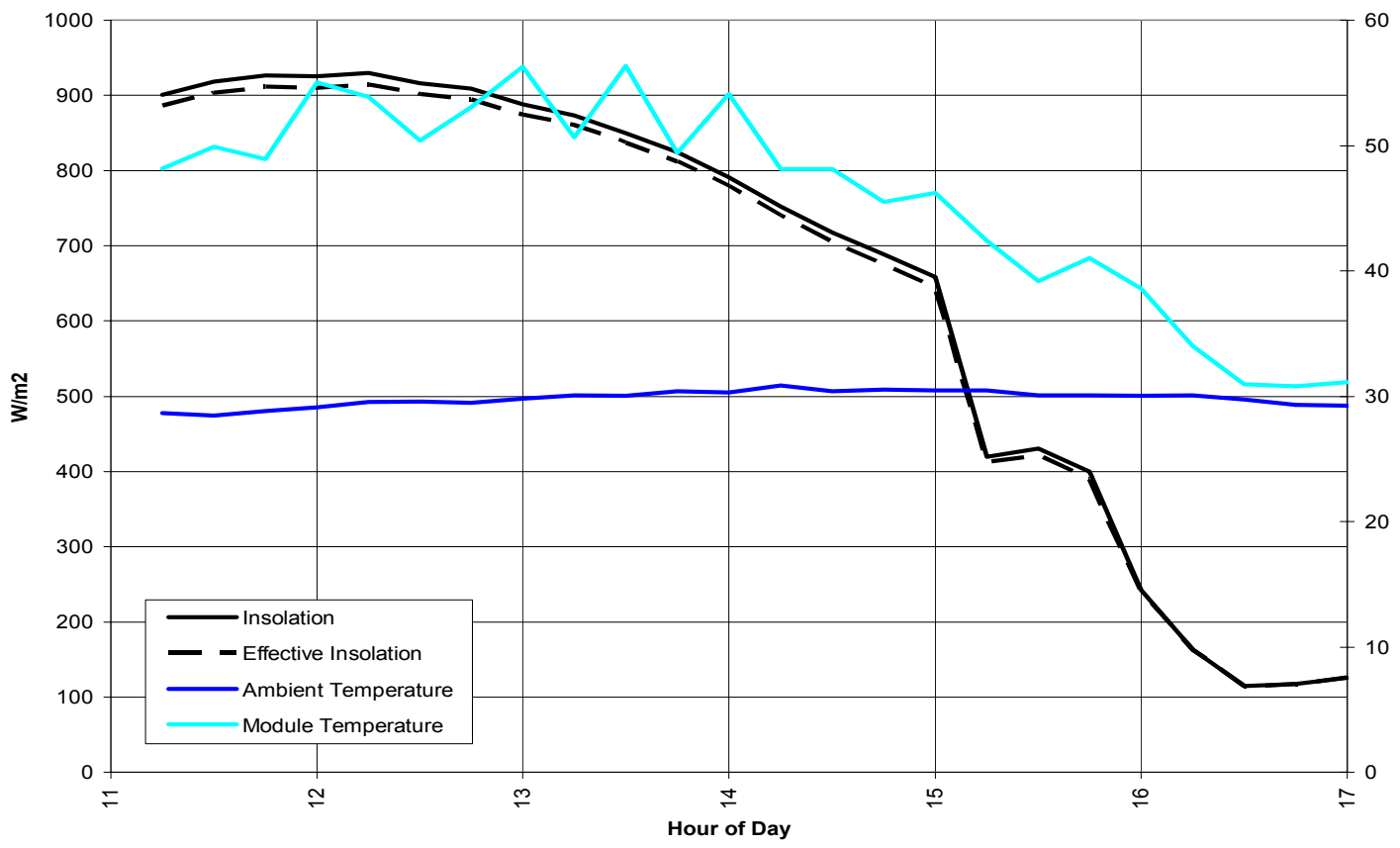

Figure 8. Conditions measured during the short-term test of the array; the calculated effective radiation (Ic,eff) is shown as a dashed line 
By applying equations 4 through 9 to the data set and performing a linear least-squares regression to determine each coefficient, we arrive at the parameters listed in Table 8. Note that temperature coefficients for currents were not calculated from regression because these are very small numbers and are, therefore, difficult to determine from a limited data set such as this one.

Figure 9 plots $V_{m p}$, adjusted for insolation effects using the results of the regression so that each point represents $V_{m p}$ at $I_{c}=1000 \mathrm{~W} / \mathrm{m}^{2}$. Measured and predicted from regression are co-plotted.

To compare the parameters at Standard Rating Conditions given in Table 8 to data provided by the manufacturer, we multiply voltages and voltage coefficients by the number of modules in series and currents by the number of modules in parallel. This comparison is made in Table 9 .

Annual TRNSYS simulations of the array using TMY2 data for Boulder, Colorado, give the results shown in Table 10. We simulated perfect MPPT and fixed voltage to demonstrate the performance that could be gained by replacing the currently installed fixed-voltage controller with an MPPT controller. The results show that under the fixed-voltage scenario, the annual energy delivery is about $8.5 \%$ lower than would have been expected using published module parameters and $18.8 \%$ lower under the MPPT scenario.

One "reality check" we like to make is to infer a wiring resistance from the measured and manufacturer's parameters at the maximum power point. If all of the voltage difference between $V_{m p 0}$ (measured) and $V_{m p 0}$ (manufacturer) is caused by wiring resistance, then the resistance is approximately:

$$
\mathrm{R}_{\text {wiring }}=\left(\mathrm{V}_{\mathrm{mp} 0, \text { man }}-\mathrm{V}_{\mathrm{mp} 0, \text { meas }}\right) \mathrm{i}_{\mathrm{mp} 0 \text {,man. }}
$$

From Table 9:

$$
\begin{aligned}
& \mathrm{R}_{\text {wiring }}=(34.62-30.34) / 18.24 \\
& \mathrm{R}_{\text {wiring }}=0.235 \text { ohms. }
\end{aligned}
$$

This is a plausible number for the wiring in the array; if we arrived at a number an order of magnitude larger, for instance, we would want to look for problems in the measurements, regressions, or the array itself.

Finally, as a cursory check of Equation 21 for calculating module temperature, Figure 10 compares measured and modeled module temperature during the test. The model predicts the module temperature with an RMS error of about $6 \%$ of the mean for this data set. 
Table 8. Coefficients for Predicting I-V Curve Under Any $T_{\text {mod }}$ and $I_{c}$

\begin{tabular}{lllll}
\hline Variable & Value & Units & $\begin{array}{l}\text { Relevant } \\
\text { Equation }\end{array}$ & Derived From \\
\hline $\mathrm{i}_{\mathrm{sc} 0}$ & 19.41 & amps & 4 & regression \\
$\alpha_{\mathrm{isc}}$ & 0.00167 & $1 /{ }^{\circ} \mathrm{C}$ & 4 & Sandia database \\
$\mathrm{i}_{\mathrm{x} 0}$ & 18.67 & amps & 5 & regression \\
$\mathrm{c}_{1}$ & 0.03829 & (unitless) & 5 & regression \\
$\alpha_{\mathrm{ix}}$ & 0.00138 & $1 /{ }^{\circ} \mathrm{C}$ & 5 & Equation 28 \\
$\mathrm{i}_{\mathrm{mp} 0}$ & 16.97 & amps & 6 & regression \\
$\mathrm{d}_{1}$ & 0.07660 & $($ unitless $)$ & 6 & regression \\
$\alpha_{\mathrm{imp}}$ & -0.00036 & $1 /{ }^{\circ} \mathrm{C}$ & 6 & Sandia database \\
$\mathrm{i}_{\mathrm{xx} 0}$ & 13.43 & amps & 7 & regression \\
$\mathrm{e}_{1}$ & -0.10733 & $(\mathrm{unitless})$ & 7 & regression \\
$\alpha_{\mathrm{ixx}}$ & -0.00036 & $1 /{ }^{\circ} \mathrm{C}$ & 7 & Equation 29 \\
$\mathrm{~V}_{\mathrm{mp} 0}$ & 30.34 & volts & 8 & regression \\
$\mathrm{f}_{1}$ & $-8.09 \mathrm{E}-03$ & $\mathrm{~V}-\mathrm{m}^{2} / \mathrm{W}$ & 8 & regression \\
$\mathrm{f}_{2}$ & $-8.22 \mathrm{E}-06$ & $\mathrm{~V}-\mathrm{m}^{4} / \mathrm{W}^{2}$ & 8 & regression \\
$\beta_{\mathrm{Vmp}}$ & -0.10222 & $\mathrm{~V} /{ }^{\circ} \mathrm{C}$ & 8 & regression \\
$\mathrm{V}_{\mathrm{oc} 0}$ & 40.80 & volts & 9 & regression \\
$\mathrm{g}_{1}$ & $-1.73 \mathrm{E}-03$ & $\mathrm{~V}-\mathrm{m}^{2} / \mathrm{W}$ & 9 & regression \\
$\mathrm{g}_{2}$ & $-5.63 \mathrm{E}-06$ & $\mathrm{~V}-\mathrm{m}^{4} / \mathrm{W}{ }^{2}$ & 9 & regression \\
$\beta_{\mathrm{Voc}}$ & -0.10616 & $\mathrm{~V} /{ }^{\circ} \mathrm{C}$ & 9 & regression \\
\hline & & & & \\
\hline & & & 9 & \\
\hline
\end{tabular}



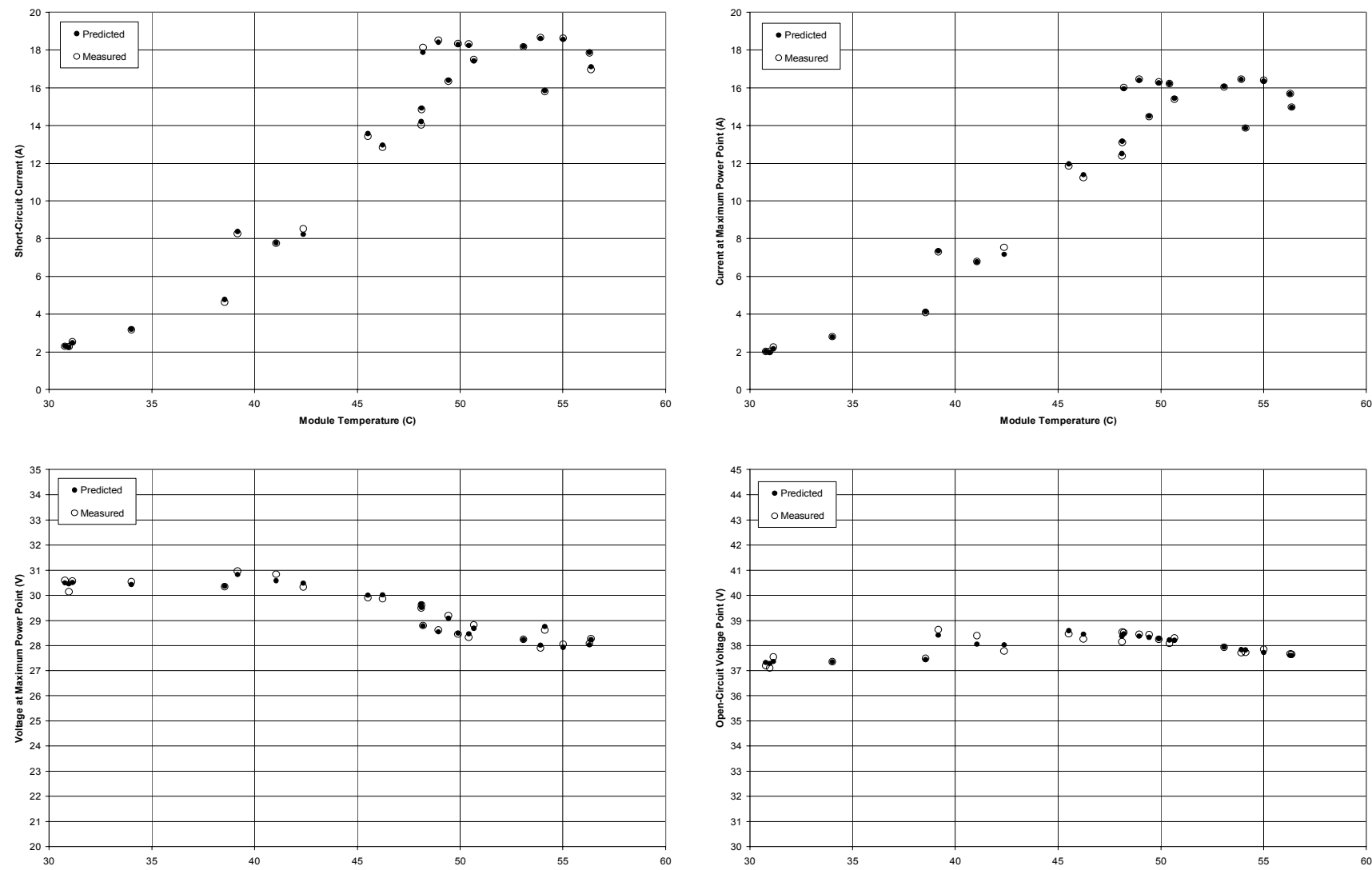

Figure 9. Key array parameters, measured and predicted from regression
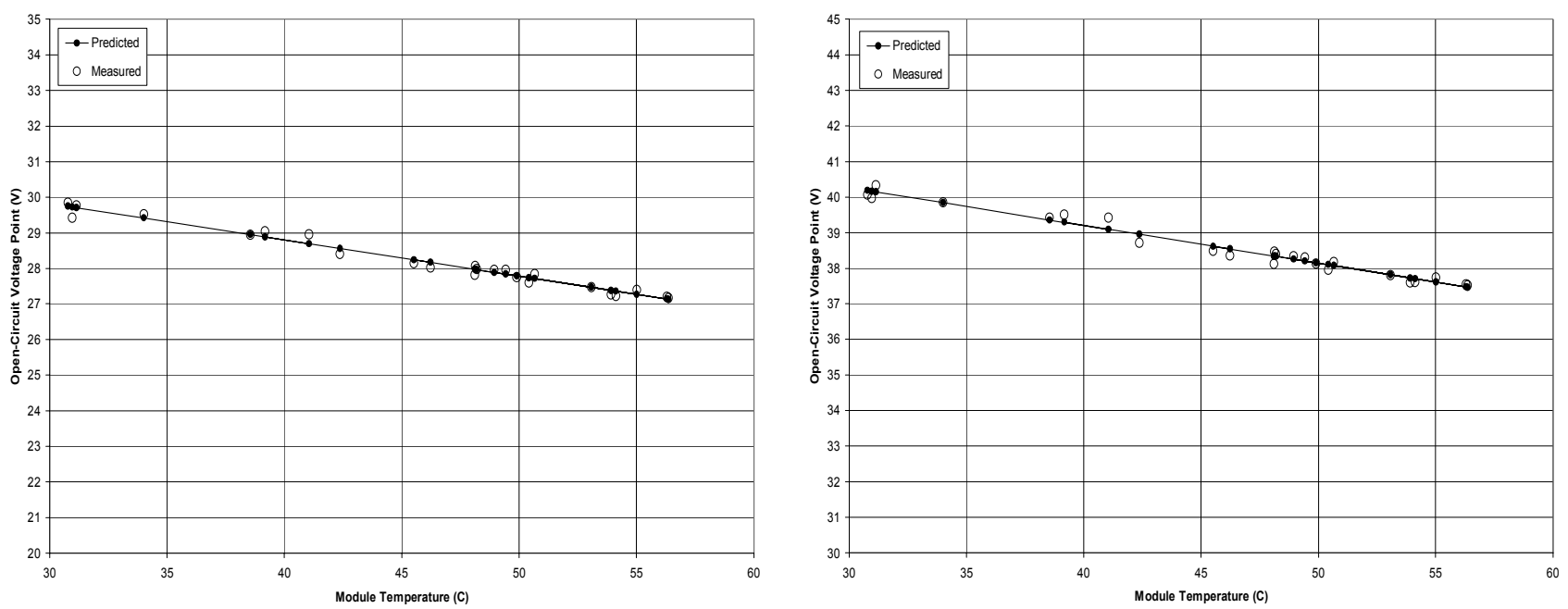

Figure 10. Effect of temperature on Vmp and Voc, measured and best-fit 
Table 9. Parameters for the PV Array at SRC

\begin{tabular}{cccc}
\hline Parameter & From Manufacturer & Measured & Units \\
\hline $\mathrm{i}_{\mathrm{sc}}$ & 19.86 & 19.41 & amps \\
$\mathrm{i}_{\mathrm{mp}}$ & 18.24 & 16.97 & amps \\
$\mathrm{V}_{\mathrm{mp}}$ & 34.62 & 30.34 & volts \\
$\mathrm{V}_{\mathrm{oc}}$ & 42.80 & 40.80 & volts \\
$\beta_{\mathrm{Voc}}$ & -0.16700 & -0.10616 & $\mathrm{~V} /{ }^{\circ} \mathrm{C}$ \\
\hline
\end{tabular}

Table 10. TRNSYS Simulation Results

\begin{tabular}{ccc}
\hline $\begin{array}{c}\text { Parameters } \\
\text { Used }\end{array}$ & $\begin{array}{c}\text { Array } \\
\text { Voltage }\end{array}$ & $\begin{array}{c}\text { Annual DC Energy } \\
\text { Delivered (kWh/yr) }\end{array}$ \\
\hline Published & 26.8 & 72.1 \\
Published & MPPT & 89.0 \\
Measured & 26.8 & 66.0 \\
Measured & MPPT & 72.3 \\
\hline
\end{tabular}

\section{Future Work}

The accuracy of the analysis method outlined in this report should be tested under the following conditions:

(1) Compare long-term measured performance data to predictions using the model provided by this method and actual measured weather data

(2) Compare parameter predictions (isc0, ix 0, ixx0, imp0, Vmp0, Voc0) from tests performed under different weather conditions (i.e., summer and winter)

(3) Compare I-V curves measured under one set of conditions (e.g., summer) to curves predicted using test results under different conditions (e.g., winter). 


\section{Nomenclature}

\begin{tabular}{|c|c|c|}
\hline Symbol & Description & Units \\
\hline a & constant in $\mathrm{T}_{\text {mod }}$ Equation 20 & \\
\hline b & constant in $\mathrm{T}_{\bmod }$ Equation 20 & \\
\hline $\mathrm{C}_{1}$ & constant $\# 1$ in $i_{x}$ polynomial fit & \\
\hline $\mathrm{c}_{2}$ & constant \#2 in $i_{x}$ polynomial fit & \\
\hline$c_{h}$ & coefficient for $h_{c}$ & \\
\hline d & distance between back of array and roof (standoff-mount) & $\mathrm{m}$ \\
\hline$d_{1}$ & constant \#1 in $i_{m p}$ polynomial fit & \\
\hline$d_{2}$ & constant \#2 in $\mathrm{i}_{\mathrm{mp}}$ polynomial fit & \\
\hline$e_{1}$ & constant $\# 1$ in $\mathrm{i}_{\mathrm{xx}}$ polynomial fit & \\
\hline$e_{2}$ & constant \#2 in $\mathrm{i}_{\mathrm{xx}}$ polynomial fit & \\
\hline $\mathrm{E}_{\mathrm{rms}}$ & $\begin{array}{l}\text { RMS error between measured and } \\
\text { calculated values of } i_{x} \text { and } i_{x x}\end{array}$ & momp \\
\hline $\mathrm{F}_{\mathrm{cc}}$ & fraction of sky covered by opaque clouds & amps \\
\hline $\mathrm{F}_{\mathrm{e}}$ & back panel surface emissivity factor & \\
\hline $\mathrm{F}_{\mathrm{b}}$ & back panel surface configuration factor & \\
\hline$f_{1}$ & constant $\# 1$ in $V_{\mathrm{mp}}$ polynomial fit & $V-m^{2} / W$ \\
\hline$f_{2}$ & constant \#2 in $\mathrm{V}_{\mathrm{mp}}$ polynomial fit & $V-m^{4} / W^{2}$ \\
\hline$g_{1}$ & constant \#1 in $V_{\text {oc }}$ polynomial fit & $V-m^{2} / W$ \\
\hline$g_{2}$ & constant \#2 in $V_{\text {oc }}$ polynomial fit & $V-m^{4} / W^{2}$ \\
\hline $\mathrm{h}_{\mathrm{cf}}$ & convective heat transfer coefficient for array front surface & $\mathrm{W} / \mathrm{m}^{2}-{ }^{\circ} \mathrm{C}$ \\
\hline $\mathrm{h}_{\mathrm{cb}}$ & convective heat transfer coefficient for array back surface & $\mathrm{W} / \mathrm{m}^{2}-{ }^{\circ} \mathrm{C}$ \\
\hline$h_{\mathrm{ri}}$ & convection coefficient on inside of roof decking & $\mathrm{W} / \mathrm{m}^{2}-{ }^{\circ} \mathrm{C}$ \\
\hline $\mathrm{I}_{\mathrm{C}}$ & incident solar radiation & $\mathrm{W} / \mathrm{m}^{2}$ \\
\hline $\mathrm{I}_{\mathrm{c}, \mathrm{eff}}$ & effective incident solar radiation & $\mathrm{W} / \mathrm{m}^{2}$ \\
\hline $\mathrm{I}_{\mathrm{c} 0}$ & incident solar radiation at SRC $\left(=1000 \mathrm{~W} / \mathrm{m}^{2}\right)$ & $\mathrm{W} / \mathrm{m}^{2}$ \\
\hline $\mathrm{I}_{\mathrm{dh}}$ & total diffuse radiation on horizontal surface & $\mathrm{W} / \mathrm{m}^{2}$ \\
\hline$I_{h}$ & total solar radiation on horizontal surface & $\mathrm{W} / \mathrm{m}^{2}$ \\
\hline $\mathrm{i}$ & current output of array & amps \\
\hline $\mathrm{i}_{\mathrm{L}}$ & "light current" for single diode model & amps \\
\hline$i_{m p}$ & current at maximum power point & amps \\
\hline $\mathrm{i}_{\mathrm{mp0}}$ & current at maximum power point at SRC & amps \\
\hline $\mathrm{i}_{\mathrm{mp0}, \mathrm{man}}$ & current at maximum power point at SRC (manufacturer) & amps \\
\hline $\mathrm{i}_{0}$ & "diode current" for single diode model & amps \\
\hline$\dot{i}_{\mathrm{sc}}$ & short-circuit current of array & amps \\
\hline $\mathrm{i}_{\mathrm{sc0}}$ & short-circuit current of array at SRC & amps \\
\hline $\mathrm{i}_{\text {TRW }}$ & current predicted using Equation 10 (“TRW equation") & amps \\
\hline $\mathrm{i}_{\mathrm{x}}$ & current output of array at $V=0.5^{\star} V_{o c}$ & amps \\
\hline$\hat{i_{x 0}}$ & current output of array at $\mathrm{V}=0.5^{\star} \mathrm{V}_{\mathrm{oc}}$, at $\mathrm{SRC}$ & amps \\
\hline $\mathrm{i}_{x \times 0}$ & current output of array at $\mathrm{V}=0.5^{*}\left(\mathrm{~V}_{\mathrm{mp}}+\mathrm{V}_{\mathrm{oc}}\right)$, at $\mathrm{SRC}$ & amps \\
\hline $\mathrm{i}_{x, \text { meas }}$ & measured value of $i_{x}$ & \\
\hline $\mathrm{i}_{\mathrm{x}, \text { calc }}$ & calculated value of $\hat{i_{x}}$ using Equation 19 & amps \\
\hline $\mathrm{i}_{\mathrm{xx} \text {,meas }}$ & measured value of $\hat{i}_{x x}$ & \\
\hline $\mathrm{i}_{\mathrm{x}, \text {,calc }}$ & calculated value of $\mathrm{i}_{\mathrm{xx}}$ using Equation 19 & amps \\
\hline & coefficient in the TRW equation & \\
\hline $\mathrm{k}_{2}$ & coefficient in the TRW equation & \\
\hline$L^{2}$ & length of array from bottom edge to top edge & $\mathrm{m}$ \\
\hline $\mathrm{P}_{\mathrm{atm}}$ & atmospheric pressure & $\mathrm{kPa}$ \\
\hline$r_{\alpha}$ & ratio of $\alpha_{\text {imp }}$ to $\alpha_{\text {isc }}$ & \\
\hline $\mathrm{R}_{\mathrm{s}}$ & series resistance for single diode model & ohms \\
\hline $\mathrm{R}_{\mathrm{sh}}$ & shunt resistance for single diode model & ohms \\
\hline $\mathrm{R}_{\text {wiring }}$ & total resistance of array wiring & ohms \\
\hline
\end{tabular}




\begin{tabular}{|c|c|c|}
\hline $\begin{array}{l}\mathrm{r}_{\beta} \\
\mathrm{SRC}\end{array}$ & $\begin{array}{l}\text { ratio of } \beta_{\mathrm{Vmp}} \text { to } \beta_{\mathrm{Voc}} \\
\text { Standard Rating Conditions }\left(\mathrm{I}_{\mathrm{c}}=1000 \mathrm{~W} / \mathrm{m}^{2}, \mathrm{Tc}=25^{\circ} \mathrm{C}\right)\end{array}$ & \\
\hline$T_{a}$ & ambient air temperature & ${ }^{\circ} \mathrm{C}$ \\
\hline $\mathrm{T}_{\mathrm{cb}}$ & temperature to which back of modules convect or conduct heat & ${ }^{\circ} \mathrm{C}$ \\
\hline $\mathrm{T}_{\mathrm{c}}$ & cell temperature & ${ }^{\circ} \mathrm{C}$ \\
\hline $\mathrm{T}_{\mathrm{c}, \max }$ & cell temperature with no heat loss from back side & ${ }^{\circ} \mathrm{C}$ \\
\hline $\mathrm{T}_{\mathrm{c} 0}$ & cell temperature at SRC & ${ }^{\circ} \mathrm{C}$ \\
\hline $\mathrm{T}_{\mathrm{cf}}$ & temperature to which front of modules convect or conduct heat & ${ }^{\circ} \mathrm{C}$ \\
\hline$T_{d p}$ & dewpoint temperature & ${ }^{\circ} \mathrm{C}$ \\
\hline$T_{i}$ & indoor temperature (may be attic) & ${ }^{\circ} \mathrm{C}$ \\
\hline$t_{\text {LST }}$ & local standard time & hours \\
\hline $\mathrm{T}_{\mathrm{mb}}$ & temperature of back of modules & Kelvin \\
\hline $\mathrm{T}_{\mathrm{mf}}$ & $\begin{array}{l}\text { temperature of front of modules } \\
\text { front of module radiates }\end{array}$ & $\begin{array}{l}\text { Kelvin } \\
\text { Kelvin }\end{array}$ \\
\hline$T_{\text {mod }}$ & back-of-module temperature & ${ }^{\circ} \mathrm{C}$ \\
\hline$T_{\text {modo }}$ & back-of-module temperature at SRC & ${ }^{\circ} \mathrm{C}$ \\
\hline $\mathrm{T}_{\mathrm{Rb}}$ & $\begin{array}{l}\text { effective black-body radiant temperature to which } \\
\text { back of module radiates }\end{array}$ & Kelvin \\
\hline$T_{\mathrm{Rf}}$ & effective black-body radiant temperature to which & \\
\hline & front of module radiates & Kelvin \\
\hline $\mathrm{T}_{\text {sky }}$ & effective black-body sky temperature & Kelvin \\
\hline$U_{r}$ & conductance of roof & $\mathrm{W} / \mathrm{m}^{2}-{ }^{\circ} \mathrm{C}$ \\
\hline $\mathrm{V}$ & voltage across array & volts \\
\hline $\mathrm{V}_{\mathrm{oc}}$ & open-circuit voltage across array & volts \\
\hline $\mathrm{V}_{\mathrm{oc} 0}$ & open-circuit voltage across array atSRC & volts \\
\hline $\mathrm{V}_{\mathrm{mp}}$ & voltage at maximum power point & volts \\
\hline $\mathrm{V}_{\mathrm{mp} 0, \mathrm{man}}$ & voltage at maximum power point (manufacturer's data) & volts \\
\hline$V_{\text {mp0,meas }}$ & voltage at maximum power point (measured data) & volts \\
\hline $\mathrm{V}_{\mathrm{mp0}}$ & voltage at maximum power point @SRC & volts \\
\hline & wind speed & $\mathrm{m} / \mathrm{sec}$ \\
\hline Warray & horizontal dimension (width) of array & $\mathrm{m}$ \\
\hline z & curve-fitting parameter for single diode model & \\
\hline$\alpha_{\text {imp }}$ & temperature coefficient for $i_{m p}$ & $1 /{ }^{\circ} \mathrm{C}$ \\
\hline$\alpha_{\text {isc }}$ & temperature coefficient for $i_{s c}$ & $1 /{ }^{\circ} \mathrm{C}$ \\
\hline$\alpha_{\mathrm{ix}}$ & temperature coefficient for $i_{x}$ & $1 /{ }^{\circ} \mathrm{C}$ \\
\hline$\alpha_{\mathrm{ixx}}$ & temperature coefficient for $i_{x x}$ & $1 /{ }^{\circ} \mathrm{C}$ \\
\hline$\beta$ & slope of array from horizontal & degrees \\
\hline$\beta_{\mathrm{Vmp}}$ & temperature coefficient for $V_{m p}$ & $\mathrm{~V} /{ }^{\circ} \mathrm{C}$ \\
\hline$\beta_{\text {Voc }}$ & temperature coefficient for $V_{o c}$ & $\mathrm{~V} /{ }^{\circ} \mathrm{C}$ \\
\hline$\varepsilon_{\mathrm{a}}$ & emissivity of attic floor surface & \\
\hline$\varepsilon_{\mathrm{b}}$ & emissivity of back of modules & \\
\hline$\varepsilon_{\mathrm{c}}$ & emissivity of cell material & \\
\hline$\varepsilon_{\mathrm{f}}$ & emissivity of front of modules & \\
\hline$\varepsilon_{\mathrm{r}}$ & emissivity of outside roof surface & \\
\hline$\varepsilon_{\mathrm{ri}}$ & emissivity of interior roof surface (facing attic) & \\
\hline$\tau_{\mathrm{IR}}$ & infrared transmittance of glazing material & \\
\hline$\gamma$ & temperature coefficient of efficiency & \\
\hline$\eta_{0}$ & array efficiency at SRC & \\
\hline$\sigma$ & Stefan-Boltzman constant & $\mathrm{W} / \mathrm{m}^{2}-\mathrm{K}^{4}$ \\
\hline$(\tau \alpha)$ & $\begin{array}{l}\text { transmittance-absorptance product for solar radiation } \\
\text { at the front of the array }\end{array}$ & \\
\hline
\end{tabular}




\section{References}

[1] "IV Tracer," software developed under the supervision of Sandia National Laboratories Photovoltaic Systems Department by Maui Solar Energy Software Corporation, Haiku, Hawaii. Maui Solar phone number: 808-573-6712.

[2] King, D. L., "Photovoltaic Module and Array Performance Characterization Methods for All System Operating Conditions," Proceeding of NREL/SNL Photovoltaics Program Review Meeting, November 18-22, 1996, Lakewood, Colorado, AIP Press, New York, Revised 10/10/97, 1977.

[3] Duffie, J. and Beckman, W., Solar Engineering of Thermal Processes, $2^{\text {nd }}$ Edition, John Wiley \& Sons, Inc., New York, pg. 119-121, 1991.

[4] Klein, S., et al., TRNSYS: A Transient System Simulation Program-Reference Manual, Solar Energy Laboratory, University of Wisconsin, 1996.

[5] Marion, W. and Urban, K., User's Manual for TMY2s (Typical Meteorological Years) Derived from the 1961-1990 National Solar Radiation Database, NREL/TP-463-7668, Golden, CO: National Renewable Energy Laboratory (NTIS/GPO Number DOE 95004064), 1995.

[6] King, D. L., "Photovoltaic Module and Array Performance Characterization Methods for All System Operating Conditions," Proceeding of NREL/SNL Photovoltaics Program Review Meeting, November 18-22, 1996, Lakewood, Colorado, AIP Press, New York, 1997.

[7] King, D. L., Kratochvil, J. A., and Boyson, W. E., "Field Experience With a New Performance Characterization Procedure for Photovoltaic Arrays," $2^{\text {nd }}$ World Conference and Exhibition on PV Solar Energy Conversion, Vienna, Austria, 1998.

[8] Erbs, D. G., Methods For Estimating the Diffuse Fraction of Hourly, Daily, and Monthly Average Global Solar Radiation, Masters Thesis in Mechanical Engineering, University of Wisconsin, Madison, 1980.

[9] Hay, J. E., and J. A. Davies, "Calculation of the Solar Radiation Incident on an Inclined Surface," in Proceedings, First Canadian Solar Radiation Data Workshop, J. E. Hay and T. K. Won, eds., Toronto, Ontario, Canada, 1978.

[10] Luft, W., Barton, J. R., and Conn, A. A., "Multifaceted Solar Array Performance Determination,” TRW Systems Group, Redondo Beach, California, February, 1967.

[11] Hart, G. W., Raghuraman, P., "Electrical Aspects of Photovoltaic System Simulation," Massachusetts Institute of Technology, Lincoln Laboratory, Lexington, MA, 1982.

[12] Press, W. H., Teukolsky, S. A., Vetterling, W. T., B. P. Flannery, Numerical Recipes, Cambridge University Press, page 292, 1989. 
[13] del Cueto, J. A., Model for the Thermal Characteristics of Flat-Plate Photovoltaic Modules Deployed at Fixed Tilt. Conference Record of the Twenty-Eighth IEEE Photovoltaic Specialists Conference--2000, 15-22 September 2000, Anchorage, Alaska. Piscataway, NJ: Institute of Electrical and Electronics Engineers, Inc.; pp. 1441-1445; NREL Report No. CP-520-28929, 2000.

[14] Jones, A. D. and Underwood, C. P., “A Thermal Model for Photovoltaic Systems,” Solar Energy Vol. 70 (4), pp. 349-359, 2001.

[15] Davis, M. W., Fanney, A. F., and Dougherty, B. P., 2001, "Prediction of Building Integrated Photovoltaic Cell Temperatures," Proceedings of Solar Forum 2001, ASME, April 21-25.

[16] Ingersoll, J. G., 1986, "Simplified Calculation of Solar Cell Temperatures in Terrestrial Photovoltaic Arrays," Journal of Solar Energy Engineering Vol. 108, pp. 95-101.

[17] Marin, M. and Berndahl, P., 1984, "Summary of Results from the Spectral and Angular Sky Radiation Measurement Program" Solar Energy, Vol. 33 (3/4), p. 241-252.

[18] Kasten, F., and Czeplak, G., "Solar and terrestrial radiation dependent on the amount and type of cloud," Solar Energy, Vol. 24 (2), 1980, pp. 177-189. Victoria, Australia: Pergamon Press. 


\section{Appendix. Code Example in Visual Basic}

The following computer code is an example in Visual Basic of iterative technique for calculating apparent beam radiation in the plane of the pyranometer.

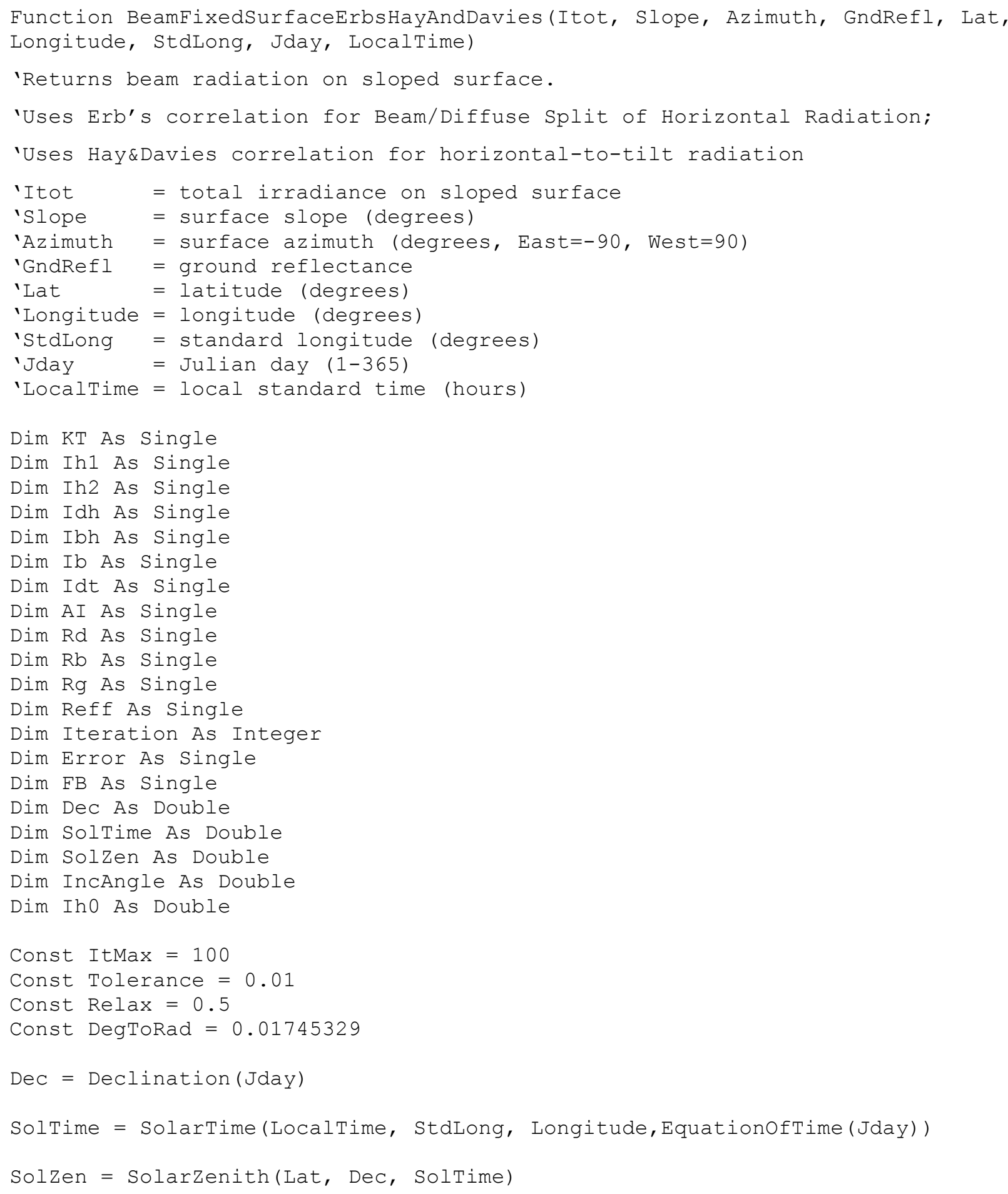




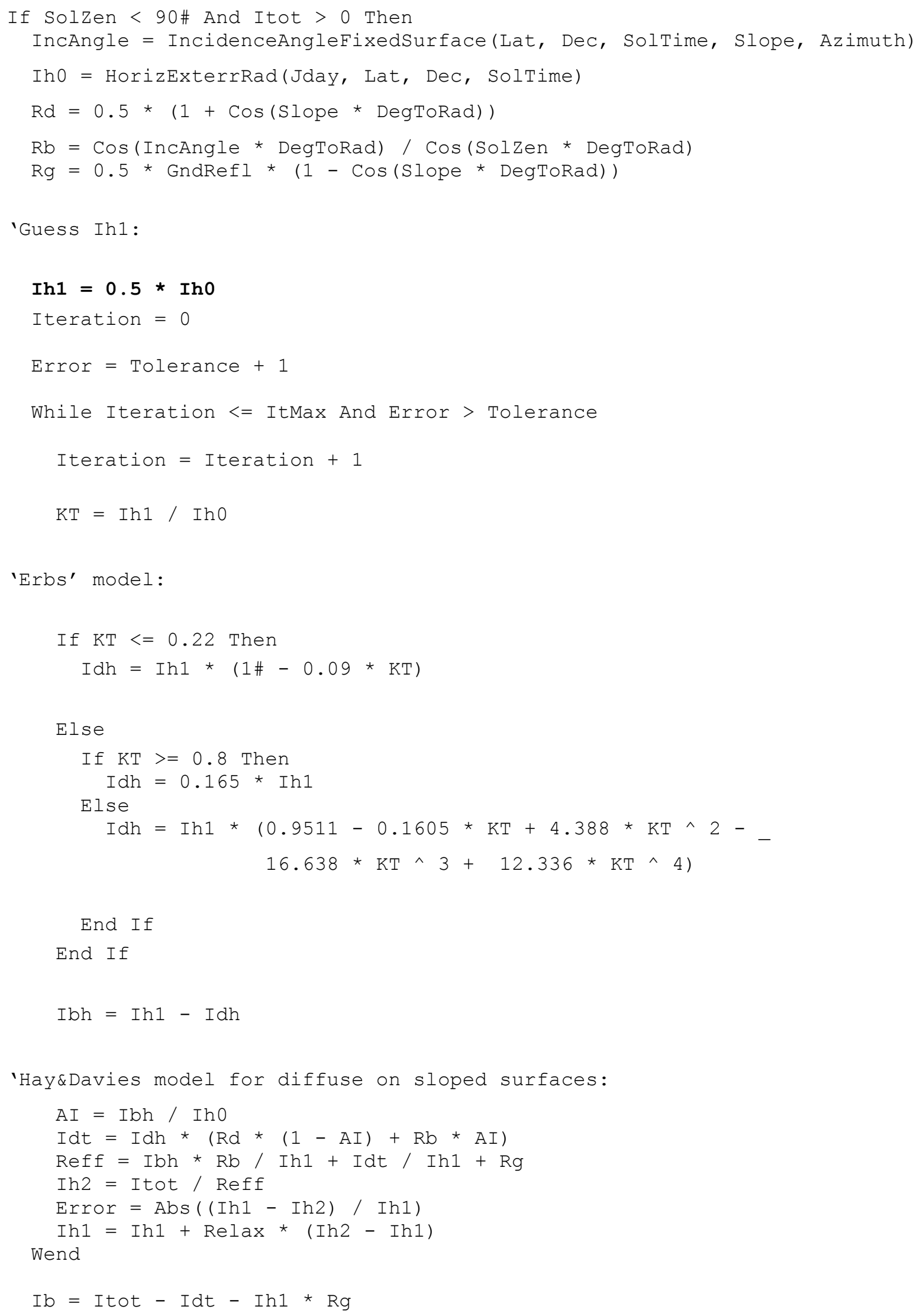




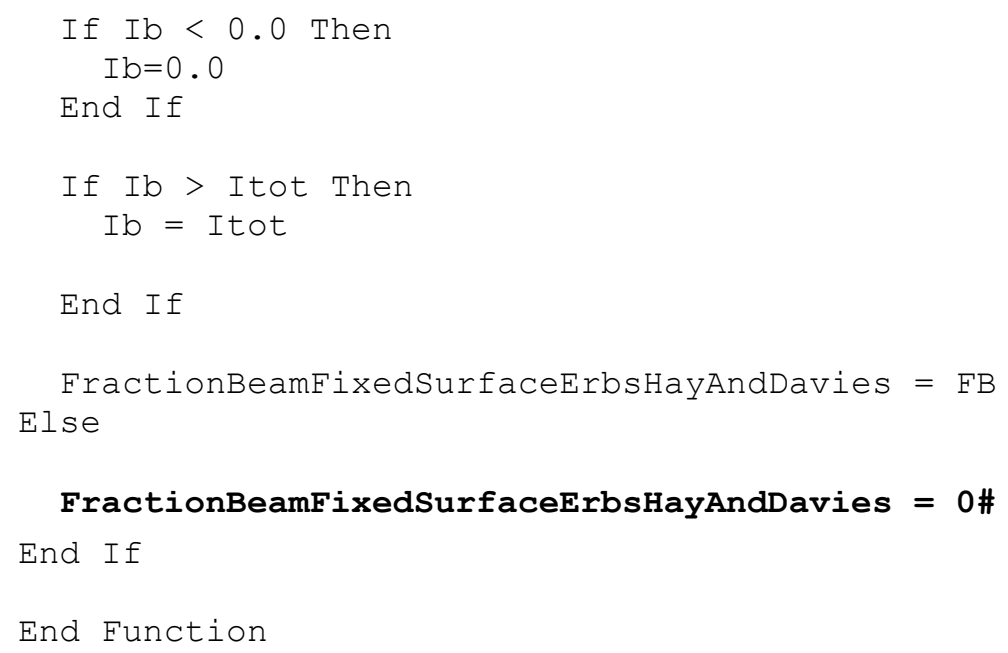




\section{REPORT DOCUMENTATION PAGE}

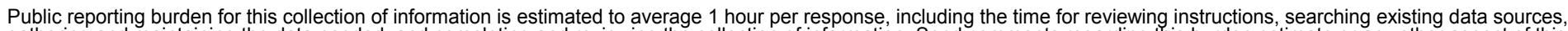

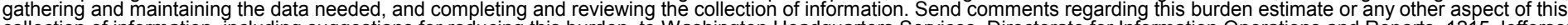

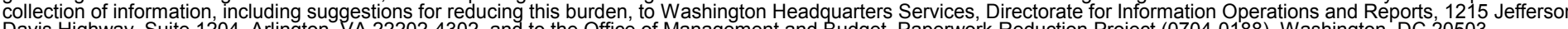

Davis Highway, Suite 1204, Arlington, VA 22202-4302, and to the Office of Management and Budget, Paperwork Reduction Project (0704-0188), Washington, DC 20503.
1. AGENCY USE ONLY (Leave blank)
2. REPORT DATE
May 2003
3. REPORT TYPE AND DATES COVERED
Technical Report

4. TITLE AND SUBTITLE

Building America System Performance Test Practices: Part 1 - Photovoltaic Systems

5. FUNDING NUMBERS

6. $\mathrm{AUTHOR}(\mathrm{S})$

G. Barker and P. Norton

BET3.8004

7. PERFORMING ORGANIZATION NAME(S) AND ADDRESS(ES)

National Renewable Energy Laboratory

1617 Cole Blvd.

Golden, CO 80401-3393

9. SPONSORING/MONITORING AGENCY NAME(S) AND ADDRESS(ES)

8. PERFORMING ORGANIZATION REPORT NUMBER

NREL/TP-550-30301

10. SPONSORING/MONITORING AGENCY REPORT NUMBER

11. SUPPLEMENTARY NOTES

12a. DISTRIBUTION/AVAILABILITY STATEMENT

National Technical Information Service

12b. DISTRIBUTION CODE

U.S. Department of Commerce

5285 Port Royal Road

Springfield, VA 22161

1. 13. ABSTRACT (Maximum 200 words) The report outlines the short-term field testing used by Building America staff and includes a report on the results of an example test of a PV system with battery storage on a home in Tucson, Arizona. This report is not intended as a general recommended test procedure for wide distribution. It is intended to document current practices in Building America to inform program stakeholders and stimulate further discussion. Building America staff intend to apply this procedure until relevant standards for testing PV modules are completed.

14. SUBJECT TERMS

Building America; PV; photovoltaic systems; U.S. Department of Energy; House Performance Test Practices; energy efficient homes

15. NUMBER OF PAGES

16. PRICE CODE

17. SECURITY CLASSIFICATION OF REPORT

Unclassified

18. SECURITY CLASSIFICATION OF THIS PAGE Unclassified
19. SECURITY CLASSIFICATION OF ABSTRACT

Unclassified
20. LIMITATION OF ABSTRACT

UL 